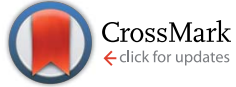

Cite this: RSC Adv., 2017, 7, 7092

Received 13th October 2016 Accepted 13th November 2016

DOI: $10.1039 / c 6 r a 25208 g$

www.rsc.org/advances

\section{Assessment of certain ionic liquids for separation of binary mixtures based on gamma infinity data measurements $\uparrow$}

\begin{abstract}
M. Karpińska, ${ }^{a}$ M. Wlazło, ${ }^{a}$ D. Ramjugernath, ${ }^{b}$ P. Naidoo ${ }^{b}$ and U. Domańska*ab
The effect of interactions between organic solvents or water on the interfacial and bulk properties of 1-benzyl-3-methylimidazolium dicyanamide, [BzMIM][DCA] and 1-benzyl-3-methylimidazolium bis $\left\{\right.$ (trifluoromethyl)sulfonyl\}imide, [BzMIM] $\left[\mathrm{NTf}_{2}\right]$ were determined via measurement of activity coefficients $\gamma_{13}^{\infty}$ at infinite dilution for 64 solutes. The data were obtained using the gas-liquid chromatography technique. Measurements were undertaken at six temperatures, in $10 \mathrm{~K}$ intervals, in the range of 318.15 to $368.15 \mathrm{~K}$. The solutes studied included both non-polar and polar compounds, such as alkanes, alkenes, and alkynes, as well as aromatic hydrocarbons, alcohols, water, ethers, ketones, acetonitrile, pyridine, 1-nitropropane, thiophene, and esters. Density, $\rho$, and viscosity $\eta$, measurements for a range of temperatures, $T$ for the chosen ionic liquids (ILs), [BzMIM][DCA] and [BzMIM] $\left[N \mathrm{NT}_{2}\right]$ were also undertaken at pressure, $p=101 \mathrm{kPa}$. The gas-liquid partition coefficients, $K_{\mathrm{L}}$ at infinite dilution, and the fundamental thermodynamic functions, partial molar excess Gibbs energy, enthalpy and entropy at infinite dilution were calculated from the experimental data measurements. The values of selectivity and capacity for three separation cases, viz. hexane/hex-1-ene, cyclohexane/cyclohexene, and ethylbenzene/styrene were calculated from $\gamma_{13}^{\infty}$ values and compared to literature for imidazolium-based or dicyanamidebased, or bis\{(trifluoromethyl)sulfonyl\}imide-based ionic liquids (ILs). The results from the study indicate that [BzMIM][DCA] has large selectivity values for all three of the separation cases studied.
\end{abstract}

\section{Introduction}

Ionic liquids (ILs) are nonvolatile salts with some rather unusual properties, such as high thermal stability, nonflammability, and high solvation properties. They have been widely studied, and have been proposed as potential replacement solvents for conventional organic solvents ${ }^{\mathbf{1 - 5}}$ in separation processes. Examples of studies considering ILs for separation include extraction of aromatic hydrocarbons from alkanes, ${ }^{5}$ desulphurization and denitrification of diesel oil, ${ }^{6-8}$ and extraction of butan-1-ol from water. ${ }^{9}$

Among the many potential separation applications, one of the most relevant is the employment of ILs as extractants for separation of alkenes from alkanes. Alkenes are particularly

${ }^{a}$ Department of Physical Chemistry, Faculty of Chemistry, Warsaw University of Technology, Noakowskiego 3, 00-664 Warsaw, Poland. E-mail: ula@ch.pw.edu.pl; Fax: +4822 6282741; Tel: +48226213115

${ }^{b}$ Thermodynamic Research Unit, School of Chemical Engineering, University of KwaZulu-Natal, Howard College Campus, King George V Avenue, Durban 4001, South Africa

$\dagger$ Electronic supplementary information (ESI) available: The sources and mass fraction purities of materials. Mean column pressure, $\bar{p}$, inlet column pressure, $p_{\mathrm{i}}$, outlet column pressure, $p_{\mathrm{o}}$ and standard state of solutes at given temperatures, at standard state. Plots of $\ln \left(\gamma_{13}^{\infty}\right)$ versus $1 / T$ for the organic solute in ILs. See DOI: 10.1039/c6ra25208g useful as substrates for the production of polymers and petrochemicals. The conventional separation technique for the alkane/alkene system is by distillation. Distillation processes can be extremely energy-intensive and technologically complex. Other separation methods, such as membranes technology or adsorption processes generally achieve a poor separation selectivity. Over the last decade, the adsorption of alkenes onto carbon, or zeolite A, or zeolite imidazolate framework ZIF-7, or metal-organic frameworks (MOFs) instant zeolites have been proposed as feasible, economical, and green alternatives to distillation. ${ }^{\mathbf{1 0 - 1 2}}$

Preliminary information about suitable solvents for separation can be obtained from activity coefficients measurements at infinite dilution $\left(\gamma_{13}^{\infty}\right)$ by the gas-liquid chromatography (GLC) technique. Solvent suitability can also be determined from liquid-liquid phase equilibrium measurements in ternary systems. The information obtained from infinite dilution activity coefficients and liquid-liquid equilibrium measurement is generally the first step in the engineering design process to determine the most suitable extraction and separation processes. The use of predictive models, such as Mo UNIFAC, PC SAFT, or COSMO RS are to date not accurate and reliable enough for the design of separation processes and restricted to the description of simple systems only. Thus, the importance and need for experimental data. In this study we 
propose to estimate the solvent separation ability for some ILs by an analysis of their selectivities and capacities, calculated from $\gamma_{13}^{\infty}$ values.

The present work is focused on new attractive ILs, namely 1-benzyl-3-methylimidazolium dicyanamide, [BzMIM][DCA] and 1-benzyl-3-methylimidazolium bis\{(trifluoromethyl) sulfonyl\}imide, [BzMIM $]\left[\mathrm{NTf}_{2}\right]$. In recent years ILs have been widely promoted as solvents for alkane/alkene separations. ${ }^{\mathbf{1 3 - 1 6}}$ The study of alkane/alkene separations using ILs reported in the literature deal mostly with short chain hydrocarbons. The imidazolium-based ILs were proposed for the propane/prop-1ene $^{\mathbf{1 3}}$ and the hexane/hex-1-ene separations. ${ }^{\mathbf{1 4}}$ Usually, an increase of the substituent size leads to a decrease of the separation factor and to an increase in the capacity. ${ }^{\mathbf{1 3 , 1 4}}$

Recently, $\gamma_{13}^{\infty}$ data were measured by us for 1-butyl-3methylimidazolium dicyanamide, [BMIM][DCA $]^{15}$ and 1-allyl3-methylimidazolium dicyanamide, [AMIM $][\mathrm{DCA}] .{ }^{16}$ These measurements revealed a very promising selectivity and capacity for the hexane/hex-1-ene, cyclohexane/cyclohexene, and ethylbenzene/styrene seperation processes.

The comparison of different ILs, applied for the alkane/ alkene separation may be performed from the data reported in the review of Domańska et al. ${ }^{15}$ Interestingly, high selectivity for the hexane/hex-1-ene separation were obtained for the ILs containing $\mathrm{CN}$ - groups substituted on the cation or anion. High selectivitities whereas observed for 1-ethyl-3-methylimidazolium dicyanamide, $\quad[$ EMIM $][\mathrm{DCA}],{ }^{17} \quad$ 1-(3-cyano-propyl)-3-methylimidazolium bis $\{($ trifluoromethyl $)$ sulfonyl $\}$ imide, [CN- $\left.\mathrm{C}_{3} \mathrm{MIM}\right]$ $\left[\mathrm{NTf}_{2}\right]{ }^{18}$ and 1-(3-cyano-propyl)2,4-dimethyl-imidazolium dicyanamide, $\left[\mathrm{CN}-\mathrm{C}_{3} \mathrm{MIM}\right][\mathrm{DCA}] .{ }^{18}$ The ILs with dicyanamide, or thricyanomethanide anions were also found to be very good for extraction of thiophene, or pyridine from aliphatic hydrocarbons. ${ }^{6,8,19}$ As an example, $[\mathrm{AMIM}]\left[\mathrm{NTf}_{2}\right]$ has a selectivity $\left(S_{12}^{\infty}=\right.$ $\left.\gamma_{13}^{\infty} / \gamma_{23}^{\infty}=1.94\right),{ }^{20}$ and [AMIM] [DCA $]$ has a selectivity $\left(S_{12}^{\infty}=\gamma_{13}^{\infty} /\right.$ $\left.\gamma_{23}^{\infty}=2.51\right)^{16}$ at $T=328.15 \mathrm{~K}$ in the hexane/hex-1-ene separation process. The bis $\left\{\right.$ (trifluoromethyl)sulfonyl\}imide, $\left[\mathrm{NTf}_{2}\right]$-based ILs are appropriate alternatives for apolar molecular liquids and are widely proposed as new entrainers for many processes. ${ }^{21}$

In this work we continue our investigations on the measurements of $\gamma_{13}^{\infty}$ and an analysis of the obtained

Table 2 Density, $\rho$ and viscosity, $\eta$ as a function of temperature, $T$ for investigated ILs [BzMIM][DCA] and [BzMIM] NTf $\left._{2}\right]$ at pressure $p=101$ $\mathrm{kPa}^{a}$

\begin{tabular}{|c|c|c|c|c|}
\hline \multirow[b]{2}{*}{$T / \mathbf{K}$} & \multicolumn{2}{|c|}{$[\mathrm{BzMIM}][\mathrm{DCA}]$} & \multicolumn{2}{|c|}{$[\mathrm{BzMIM}]\left[\mathrm{NTf}_{2}\right]$} \\
\hline & $\rho / \mathrm{g} \mathrm{cm}^{-3}$ & $\eta / \mathrm{mPa} \mathrm{s}$ & $\rho / \mathrm{g} \mathrm{cm}^{-3}$ & $\eta / \mathrm{mPa} \mathrm{s}$ \\
\hline 298.15 & 1.15814 & 102 & $1.49098^{b}$ & $133^{c}$ \\
\hline 303.15 & 1.15480 & - & 1.48609 & - \\
\hline 308.15 & 1.15147 & 56.1 & 1.48124 & 74.9 \\
\hline 313.15 & 1.14816 & - & 1.47644 & - \\
\hline 318.15 & 1.14488 & 34.5 & 1.47167 & 46.2 \\
\hline 323.15 & 1.14163 & - & $1.46693^{d}$ & - \\
\hline 328.15 & 1.13839 & 23.2 & 1.46222 & 30.9 \\
\hline 333.15 & 1.13517 & - & 1.45756 & - \\
\hline 338.15 & 1.13183 & 16.5 & 1.45295 & 21.9 \\
\hline 343.15 & 1.12869 & - & 1.44837 & - \\
\hline 348.15 & 1.12528 & 12.3 & 1.44381 & 16.2 \\
\hline 353.15 & 1.12201 & - & 1.43917 & - \\
\hline 358.15 & 1.11876 & 9.56 & 1.43470 & 12.4 \\
\hline 363.15 & 1.11544 & - & 1.43013 & - \\
\hline 368.15 & 1.11211 & 7.61 & 1.42554 & 9.74 \\
\hline
\end{tabular}

${ }^{a}$ Standard uncertainties $u$ are $u(T)= \pm 0.1 \mathrm{~K}, u(\rho)= \pm 1.1 \times 10^{-3} \mathrm{~g} \mathrm{~cm}^{-3}$, $u(\eta)= \pm 0.15 \%, u(p)= \pm 1 \mathrm{kPa} .{ }^{b} \rho / \mathrm{g} \mathrm{cm}^{-3}=1.491$ in ref. $23 ; 1.489$ in ref. $24 ; 1.504$ in ref. $25 ; 1.42$ in ref. 26 ; at $T=293.15 \mathrm{~K} ; 1.151$ at $T=293.15 \mathrm{~K}$ in ref. $27 ; 1.491$ (room temperature, $25^{\circ} \mathrm{C}$ ) in ref. $28 ; 1.441$ at $T=295 \mathrm{~K}$ in ref. $29 .{ }^{c} \eta / \mathrm{mPa} \mathrm{s}=113$ in ref. 23,125 in ref. $24 ; 61$ in ref. $26 ; 190$ at $T$ $=293.15 \mathrm{~K} ; 160$ at $T=293.2 \mathrm{~K}$ in ref. $27 ; 150.8$ (room temperature, $25^{\circ} \mathrm{C}$ ) in ref. $28 ; 40$ (room temperature) in ref. $22 .^{d} \rho / \mathrm{g} \mathrm{cm}^{-3}=1.458$ in ref. 23.

Table 1 The name, abbreviation, structure, midpoint glass transition temperature, $T_{\mathrm{g}}$ and change of heat capacity at the glass transition temperature, $\Delta C_{\mathrm{p}(\mathrm{g})}$ of investigated ionic liquids at pressure $p=101 \mathrm{kPa}^{a}$

Name, abbreviation 1-Benzyl-3-methylimidazolium dicyanamide, [BzMIM][DCA]

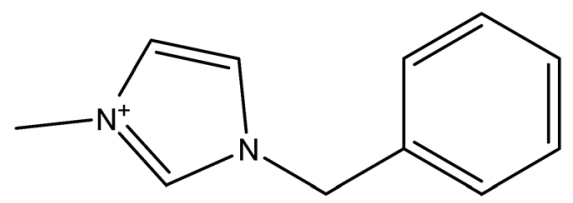

Structure

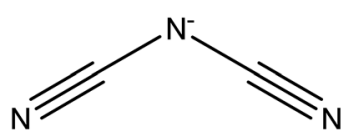

1-Benzyl-3-methylimidazolium bis\{(trifluoromethyl)sulfonyl\}imide, [BzMIM] $\left[\mathrm{NTf}_{2}\right]$

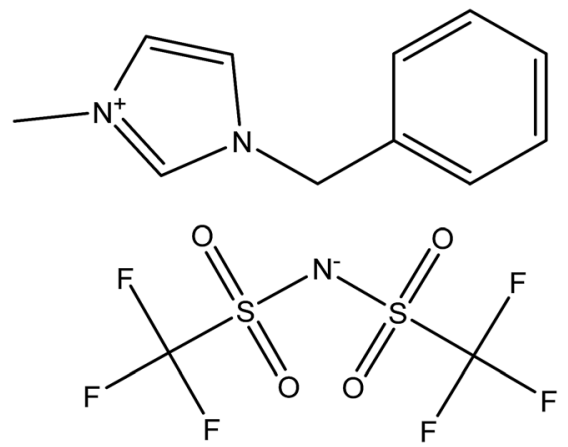
$\mathrm{M} / \mathrm{g} \mathrm{mol}{ }^{-1}$
239.28
$T_{\mathrm{g}} / \mathrm{K} \quad 217.0^{b}$
$\Delta C_{\mathrm{p}(\mathrm{g})} / \mathrm{J} \mathrm{mol}{ }^{-1} \mathrm{~K}^{-1} \quad 169.9^{b}$
453.38
$216.9^{c, d}$
$199.5^{c, d}$

${ }^{a}$ Standard uncertainties $u$ are as follows; $u\left(T_{\mathrm{g}}\right)= \pm 0.1 \mathrm{~K} ; u\left(\Delta C_{\mathrm{p}(\mathrm{g})}\right)= \pm 5 \mathrm{~J} \mathrm{~mol}^{-1} \mathrm{~K}^{-1}, u(p)= \pm 1 \mathrm{kPa} .{ }^{b} \mathrm{~A}$ midpoint $T_{\mathrm{g}} / \mathrm{K}=195.4$ with $\Delta C_{\mathrm{p}(\mathrm{g})} / \mathrm{J}$ mol ${ }^{-1}$ $\mathrm{K}^{-1}=214$ in ref. $22 .{ }^{c}$ A midpoint $T_{\mathrm{g}} / \mathrm{K}=217$ with $\Delta C_{\mathrm{p}(\mathrm{g})} / \mathrm{J} \mathrm{mol}{ }^{-1}{ }^{-1} \mathrm{~K}^{-1}=86.1$ in ref. $23 .{ }^{d}$ A midpoint $T_{\mathrm{g}} / \mathrm{K}=215.8$ in ref. $24 ; T_{\mathrm{g}} / \mathrm{K}=215.8 \mathrm{~K}$ in ref. 25 ; $T_{\mathrm{g}} / \mathrm{K}=210.8 \mathrm{~K}$ with jump $\Delta C_{\mathrm{p}(\mathrm{g})} / \mathrm{J} \mathrm{mol}^{-1} \mathrm{~K}^{-1}=197$ in ref. 22. 
Table 3 The experimental activity coefficients at infinite dilution $\gamma_{13}^{\infty}$ for the solutes in ionic liquid [BzMIM] [DCA] at different temperatures for the hypothetical liquid at zero pressure ${ }^{a}$

\begin{tabular}{|c|c|c|c|c|c|c|}
\hline \multirow[b]{2}{*}{ Solute } & \multicolumn{6}{|l|}{$T / \mathrm{K}$} \\
\hline & 318.15 & 328.15 & 338.15 & 348.15 & 358.15 & 368.15 \\
\hline Pentane & 71.4 & 65.0 & 59.5 & 54.7 & 50.5 & \\
\hline Hexane & 105 & 95.4 & 87.8 & 81.0 & 75.1 & 70.2 \\
\hline 3-Methylpentane & 95.0 & 86.1 & 78.6 & 72.2 & 66.5 & 61.7 \\
\hline 2,2-Dimethylbutane & 115 & 101 & 88.8 & 78.9 & 70.4 & \\
\hline Heptane & 159 & 144 & 132 & 121 & 111 & 103 \\
\hline Octane & 245 & 221 & 201 & 184 & 169 & 156 \\
\hline 2,2,4-Trimethylpentane & 216 & 193 & 176 & 160 & 147 & 135 \\
\hline Nonane & 372 & 332 & 299 & 271 & 247 & 227 \\
\hline Decane & 575 & 509 & 455 & 409 & 369 & 336 \\
\hline Cyclopentane & 22.2 & 21.0 & 20.0 & 19.0 & 18.2 & 17.4 \\
\hline Cyclohexane & 36.0 & 33.5 & 31.4 & 29.6 & 27.9 & 26.4 \\
\hline Methylcyclohexane & 58.7 & 54.2 & 50.3 & 46.9 & 43.9 & 41.3 \\
\hline Cycloheptane & 44.1 & 41.0 & 38.4 & 36.0 & 34.0 & 32.2 \\
\hline Cyclooctane & 58.3 & 53.9 & 50.2 & 46.9 & 44.0 & 41.5 \\
\hline Pent-1-ene & 25.8 & 24.7 & 23.7 & 22.9 & 22.1 & 21.4 \\
\hline Hex-1-ene & 40.1 & 38.1 & 36.4 & 34.7 & 33.3 & 32.1 \\
\hline Cyclohexene & 13.9 & 13.6 & 13.3 & 13.0 & 12.8 & 12.5 \\
\hline Hept-1-ene & 62.1 & 58.8 & 56.0 & 53.3 & 51.0 & 49.0 \\
\hline Oct-1-ene & 98.3 & 92.2 & 87.0 & 82.5 & 78.5 & 74.9 \\
\hline Dec-1-ene & 238 & 220 & 205 & 191 & 179 & 168 \\
\hline Pent-1-yne & 5.20 & 5.36 & 5.50 & 5.65 & 5.79 & 5.93 \\
\hline Hex-1-yne & 7.97 & 8.12 & 8.28 & 8.40 & 8.56 & 8.69 \\
\hline Hept-1-yne & 12.7 & 12.8 & 12.9 & 13.0 & 13.1 & 13.2 \\
\hline Oct-1-yne & 20.3 & 20.2 & 20.2 & 20.1 & 20.1 & 20.0 \\
\hline Benzene & 2.36 & 2.44 & 2.53 & 2.61 & 2.70 & 2.78 \\
\hline Toluene & 3.91 & 4.05 & 4.19 & 4.31 & 4.44 & 4.56 \\
\hline Ethylbenzene & 6.56 & 6.71 & 6.85 & 6.97 & 7.10 & 7.22 \\
\hline$o$-Xylene & 5.35 & 5.51 & 5.65 & 5.80 & 5.94 & 6.06 \\
\hline$m$-Xylene & 6.77 & 6.95 & 7.12 & 7.27 & 7.42 & 7.57 \\
\hline$p$-Xylene & 6.60 & 6.76 & 6.93 & 7.08 & 7.25 & 7.39 \\
\hline$n$-Propylbenzene & 10.9 & 11.0 & 11.2 & 11.3 & 11.4 & 11.6 \\
\hline Iso-propylbenzene & 10.6 & 10.9 & 11.1 & 11.3 & 11.5 & 11.7 \\
\hline Styrene & 2.97 & 3.11 & 3.23 & 3.36 & 3.49 & 3.62 \\
\hline$\alpha$-Methylstyrene & 4.77 & 5.03 & 5.29 & 5.54 & 5.80 & 6.06 \\
\hline Thiophene & 1.37 & 1.44 & 1.51 & 1.58 & 1.64 & 1.71 \\
\hline Pyridine & 0.989 & 1.03 & 1.08 & 1.12 & 1.16 & 1.21 \\
\hline Methanol & 0.503 & 0.511 & 0.518 & 0.525 & 0.533 & 0.539 \\
\hline Ethanol & 0.874 & 0.872 & 0.87 & 0.869 & 0.868 & 0.867 \\
\hline Propan-1-ol & 1.17 & 1.16 & 1.16 & 1.15 & 1.15 & 1.15 \\
\hline Propan-2-ol & 1.37 & 1.35 & 1.33 & 1.31 & 1.29 & 1.27 \\
\hline Butan-1-ol & 1.68 & 1.66 & 1.64 & 1.62 & 1.60 & 1.59 \\
\hline Butan-2-ol & 1.76 & 1.75 & 1.74 & 1.73 & 1.72 & 1.71 \\
\hline 2-Methyl-1-propanol & 1.72 & 1.68 & 1.65 & 1.62 & 1.60 & 1.57 \\
\hline tert-Butanol & 1.81 & 1.80 & 1.78 & 1.77 & 1.76 & 1.75 \\
\hline 1-Pentanol & 2.26 & 2.24 & 2.23 & 2.21 & 2.20 & 2.19 \\
\hline Water & 0.378 & 0.387 & 0.396 & 0.404 & 0.412 & 0.42 \\
\hline Methyl acetate & 1.85 & 1.94 & 2.03 & 2.11 & 2.19 & 2.28 \\
\hline Methyl propanoate & 2.77 & 2.90 & 3.03 & 3.14 & 3.26 & 3.38 \\
\hline Methyl butanoate & 4.40 & 4.55 & 4.68 & 4.81 & 4.94 & 5.07 \\
\hline Ethyl acetate & 3.11 & 3.22 & 3.34 & 3.45 & 3.56 & 3.67 \\
\hline Tetrahydrofuran & 1.71 & 1.78 & 1.86 & 1.93 & 2.00 & 2.08 \\
\hline 1,4-Dioxane & 1.09 & 1.16 & 1.23 & 1.30 & 1.37 & 1.45 \\
\hline tert-Butyl methyl ether & 11.4 & 11.5 & 11.7 & 11.8 & 12.0 & 12.1 \\
\hline tert-Butyl ethyl ether & 30.9 & 30.6 & 30.5 & 30.3 & 30.1 & 30.0 \\
\hline tert-Amyl methyl ether & 16.9 & 17.0 & 17.1 & 17.2 & 17.3 & 17.3 \\
\hline Diethyl ether & 9.88 & 9.94 & 9.99 & 10.0 & 10.1 & 10.1 \\
\hline Di- $n$-propyl ether & 32.3 & 31.6 & 31.0 & 30.4 & 29.9 & 29.4 \\
\hline Di-iso-propyl ether & 39.0 & 37.8 & 36.8 & 35.9 & 35.1 & 34.3 \\
\hline Di- $n$-butyl ether & 81.2 & 77.2 & 73.8 & 70.8 & 68.0 & 65.5 \\
\hline Acetone & 1.12 & 1.17 & 1.23 & 1.28 & 1.33 & 1.39 \\
\hline
\end{tabular}


Table 3 (Contd.)

\begin{tabular}{llllll}
\hline & \multicolumn{1}{l}{$T / \mathrm{K}$} & & & \\
\cline { 2 - 6 } Solute & 318.15 & 328.15 & 338.15 & 348.15 & 358.15 \\
\hline Pentan-2-one & 2.50 & 2.59 & 2.70 & 2.79 & 368.15 \\
Pentan-3-one & 2.52 & 2.62 & 2.73 & 2.83 & 2.89 \\
Butanal & 1.96 & 2.04 & 2.13 & 2.93 & 2.29 \\
Acetonitrile & 0.879 & 0.903 & 0.927 & 0.952 & 0.974 \\
1-Nitropropane & 1.53 & 1.58 & 1.63 & 1.68 & 1.73 \\
${ }^{a}$ Standard uncertainties $u$ are $u\left(\gamma_{13}^{\infty}\right)=3 \%, u(T)=0.02 \mathrm{~K}$. & & & & \\
\end{tabular}

selectivities and capacities for hexane/hex-1-ene, cyclohexane/ cyclohexene and ethylbenzene/styrene seperation processes. This work proposes to study a particular type of ILs, 1-benzyl-3methylimidazolium dicyanamide, [BzMIM][DCA] and 1-benzyl3-methylimidazolium bis\{(trifluoromethyl)sulfonyl\}imide, [BzMIM] $\left[\mathrm{NTf}_{2}\right]$ as a function of temperature at ambient pressure to compare the results with data previously measured by us for [AMIM][DCA] and $[\mathrm{AMIM}]\left[\mathrm{NTf}_{2}\right]$. According to many sources in literature, the high interaction of aromatic compounds, here of ethylbenzene with the IL is caused by $\pi-\pi$ interactions between the cation with the benzyl group and aromatics. Because of this, we have selected cations with the benzyl group. In this paper we report the activity coefficients $\gamma_{13}^{\infty}$ at infinite dilution, the gas-liquid partition coefficients $K_{\mathrm{L}}$ and thermodynamic functions at infinite dilution for all measured solutes. The thermodynamic properties obtained are analyzed with regard to intermolecular interactions. A physico-chemical characterization of the ILs was also performed by measuring their thermal properties with DSC, as well as densities and viscosities as a function of temperature.

\section{Materials and methods}

\section{Materials}

The ILs were purchased from Io-Li-Tec (Ionic Liquids Technologies, GmbH, Heilbronn, Germany), 1-benzyl-3methylimidazolium dicyanamide, purity $>0.98$ mass fraction; CAS: 958445-60-8, and 1-benzyl-3-methylimidazolium bis $\{$ (trifluoromethyl)sulfonyl imide, purity > 0.99 mass fraction; CAS: 433337-24-7. The names, abbreviation of names, structures, molar masses, glass transition temperatures $\left(T_{\mathrm{g}}\right)$ and heat capacity, $\left(C_{\mathrm{p}(\mathrm{g})}\right)$ values at glass transition are listed in Table 1. The different solutes, purchased from Aldrich or Fluka, had purities better than 0.99 mass fraction and were used without further purification due to the fact that the GLC technique separates any impurities on the column. The specification and purity is shown in Table $1 \mathrm{~S}$ in the ESI. $\dagger$

\section{Water content}

The water content of the solvents was analyzed by the KarlFischer titration technique (method TitroLine KF). The sample of IL, or solvent was dissolved in methanol and titrated in steps of $0.0025 \mathrm{~cm}^{3}$. The uncertainty on the water content was $u$ (w.c.) $=10 \mathrm{ppm}$ for the $3 \mathrm{~cm}^{3}$ sample of IL injected. The water content in ILs was $200 \mathrm{ppm}$ and $320 \mathrm{ppm}$ for [BzMIM][DCA] and [BzMIM $]\left[\mathrm{NTf}_{2}\right]$, respectively.

\section{Differential scanning calorimetry, DSC}

The basic thermal characteristics of ILs, i.e. temperature of glass transition and heat capacity at glass transition temperature $\left(T_{\mathrm{g}}, C_{\mathrm{p}(\mathrm{g})}\right)$ were measured using a differential scanning microcalorimetry technique (DSC). The applied scan rate was 5 $\mathrm{K} \mathrm{min}^{-1}$, with power and recorder sensitivities of $16 \mathrm{~mJ} \mathrm{~s}^{-1}$ and $5 \mathrm{mV}$, respectively. The apparatus (DSC $1 \mathrm{STAR}^{\mathrm{e}}$ System from Mettler Toledo with Liquid Nitrogen Cooling System) was calibrated with a $0.999999 \mathrm{~mol}$ fraction purity indium sample. The repeatability of the glass transition temperature value was \pm 0.1 $\mathrm{K}$. The uncertainty of the glass temperature was $u\left(T_{\mathrm{g}}\right)=0.1 \mathrm{~K}$, and that of the heat capacity at glass transition $u\left(C_{\mathrm{p}(\mathrm{g})}\right)=5 \mathrm{~J}$ $\mathrm{mol}^{-1} \mathrm{~K}^{-1}$. The DSC diagrams of the ILs are shown as Fig. 1Sa and $\mathrm{b}$ in the $\mathrm{ESI}^{\dagger}$ and the final results together with the literature data are listed in Table $1 .^{22-25}$

\section{Density measurements}

The density of the ILs was measured using an Anton Paar GmbH 4500 vibrating-tube densimeter (Graz, Austria), thermostated over a temperature range of (298.15-368.15) K. Two integrated Pt-100 platinum thermometers provided good precision in temperature control internally $(T \pm 0.01 \mathrm{~K})$. The densimeter has an automatic correction for the viscosity of the sample. The apparatus is precise to within $1 \times 10^{-5} \mathrm{~g} \mathrm{~cm}^{-3}$, and the uncertainty of the measurements was estimated to be $u(\rho)=$ $\pm 1.1 \times 10^{-3} \mathrm{~g} \mathrm{~cm}^{-3}$. The densimeter's calibration was performed at atmospheric pressure using doubly distilled and degassed water (PURE LAB Option Q Elga Water System), specially purified benzene (CHEMIPAN, Poland 0.999), and dried air. The densities of ILs are listed in Table $2 .^{23-29}$

\section{Viscosity measurements}

Viscosity measurements were carried out on an Anton Paar GmbH AMVn (Graz, Austria) programmable rheometer, with a nominal uncertainty of $\pm 0.15 \%$ and reproducibility $<0.05 \%$ for viscosities from $7.6 \mathrm{mPa}$ s to $140 \mathrm{mPa}$ s. Temperature was controlled internally with a precision of $\pm 0.01 \mathrm{~K}$ in a range from (298.15 to 368.15$) \mathrm{K}$. The diameter of the capillary was 1.8 $\mathrm{mm}$ and $3 \mathrm{~mm}$ for viscosities from (2.5 to 70$) \mathrm{mPa}$, and (20 to 
Table 4 The experimental activity coefficients at infinite dilution $\gamma_{13}^{\infty}$ for the solutes in ionic liquid [BzMIM] [NTf $f_{2}$ ] at different temperatures for the hypothetical liquid at zero pressure ${ }^{a}$

\begin{tabular}{|c|c|c|c|c|c|c|}
\hline \multirow[b]{2}{*}{ Solute } & \multicolumn{6}{|l|}{$T / \mathrm{K}$} \\
\hline & 318.15 & 328.15 & 338.15 & 348.15 & 358.15 & 368.15 \\
\hline Pentane & 13.5 & 12.9 & 12.3 & 11.8 & 11.4 & 11.0 \\
\hline Hexane & 18.4 & 17.6 & 16.8 & 16.1 & 15.5 & 14.9 \\
\hline 3-Methylpentane & 16.1 & 15.4 & 14.9 & 14.4 & 13.9 & 13.5 \\
\hline 2,2-Dimethylbutane & 15.8 & 15.1 & 14.6 & 14.1 & 13.6 & 13.2 \\
\hline Heptane & 26.2 & 24.8 & 23.5 & 22.4 & 21.4 & 20.4 \\
\hline Octane & 37.9 & 35.3 & 33.0 & 31.0 & 29.2 & 27.5 \\
\hline 2,2,4-Trimethylpentane & 26.1 & 24.9 & 23.8 & 22.8 & 21.9 & 21.1 \\
\hline Nonane & 53.2 & 49.3 & 45.9 & 42.9 & 40.2 & 37.8 \\
\hline Decane & 77.3 & 70.7 & 65.0 & 60.1 & 55.7 & 51.9 \\
\hline Cyclopentane & 6.82 & 6.61 & 6.43 & 6.28 & 6.11 & 5.98 \\
\hline Cyclohexane & 9.85 & 9.39 & 9.01 & 8.64 & 8.33 & 8.01 \\
\hline Methylcyclohexane & 13.6 & 13.0 & 12.5 & 12.0 & 11.6 & 11.2 \\
\hline Cycloheptane & 12.7 & 12.1 & 11.6 & 11.1 & 10.7 & 10.3 \\
\hline Cyclooctane & 16.5 & 15.6 & 14.8 & 14.0 & 13.3 & 12.7 \\
\hline Pent-1-ene & 6.66 & 6.61 & 6.56 & 6.52 & 6.47 & 6.43 \\
\hline Hex-1-ene & 9.53 & 9.27 & 9.05 & 8.85 & 8.65 & 8.49 \\
\hline Cyclohexene & 5.40 & 5.31 & 5.25 & 5.18 & 5.11 & 5.05 \\
\hline Hept-1-ene & 13.2 & 12.9 & 12.6 & 12.4 & 12.1 & 11.9 \\
\hline Oct-1-ene & 19.3 & 18.6 & 17.9 & 17.2 & 16.7 & 16.2 \\
\hline Dec-1-ene & 38.8 & 36.8 & 35.1 & 33.5 & 32.1 & 30.8 \\
\hline Pent-1-yne & 2.38 & 2.46 & 2.53 & 2.60 & 2.67 & 2.74 \\
\hline Hex-1-yne & 3.32 & 3.40 & 3.47 & 3.55 & 3.62 & 3.68 \\
\hline Hept-1-yne & 4.69 & 4.76 & 4.83 & 4.90 & 4.96 & 5.02 \\
\hline Oct-1-yne & 6.64 & 6.65 & 6.7 & 6.73 & 6.75 & 6.77 \\
\hline Benzene & 0.999 & 1.05 & 1.10 & 1.14 & 1.19 & 1.23 \\
\hline Toluene & 1.49 & 1.55 & 1.60 & 1.66 & 1.72 & 1.77 \\
\hline Ethylbenzene & 2.19 & 2.26 & 2.33 & 2.40 & 2.48 & 2.54 \\
\hline$o$-Xylene & 1.98 & 2.04 & 2.10 & 2.16 & 2.22 & 2.27 \\
\hline$m$-Xylene & 2.20 & 2.28 & 2.37 & 2.45 & 2.53 & 2.61 \\
\hline$p$-Xylene & 2.21 & 2.30 & 2.38 & 2.46 & 2.54 & 2.62 \\
\hline$n$-Propylbenzene & 3.17 & 3.26 & 3.35 & 3.43 & 3.52 & 3.59 \\
\hline Iso-propylbenzene & 3.11 & 3.19 & 3.27 & 3.35 & 3.43 & 3.51 \\
\hline Styrene & 1.26 & 1.32 & 1.39 & 1.46 & 1.52 & 1.59 \\
\hline$\alpha$-Methylstyrene & 1.88 & 1.98 & 2.10 & 2.20 & 2.31 & 2.42 \\
\hline Thiophene & 0.860 & 0.900 & 0.938 & 0.974 & 1.01 & 1.05 \\
\hline Pyridine & 0.487 & 0.512 & 0.537 & 0.561 & 0.586 & 0.610 \\
\hline Methanol & 1.34 & 1.28 & 1.22 & 1.16 & 1.12 & 1.07 \\
\hline Ethanol & 1.71 & 1.61 & 1.52 & 1.45 & 1.37 & 1.31 \\
\hline Propan-1-ol & 2.08 & 1.96 & 1.85 & 1.76 & 1.68 & 1.60 \\
\hline Propan-2-ol & 1.96 & 1.82 & 1.69 & 1.58 & 1.49 & 1.40 \\
\hline Butan-1-ol & 2.69 & 2.50 & 2.33 & 2.19 & 2.06 & 1.95 \\
\hline Butan-2-ol & 2.30 & 2.15 & 2.03 & 1.91 & 1.81 & 1.72 \\
\hline 2-Methyl-1-propanol & 2.64 & 2.44 & 2.25 & 2.09 & 1.95 & 1.83 \\
\hline tert-Butanol & 1.91 & 1.81 & 1.73 & 1.65 & 1.59 & 1.53 \\
\hline 1-Pentanol & 3.18 & 2.97 & 2.78 & 2.62 & 2.47 & 2.33 \\
\hline Water & 3.27 & 2.97 & 2.72 & 2.50 & 2.32 & 2.15 \\
\hline Methyl acetate & 0.603 & 0.638 & 0.673 & 0.707 & 0.742 & 0.776 \\
\hline Methyl propanoate & 0.768 & 0.814 & 0.863 & 0.909 & 0.955 & 1.00 \\
\hline Methyl butanoate & 1.09 & 1.14 & 1.19 & 1.24 & 1.29 & 1.34 \\
\hline Ethyl acetate & 0.788 & 0.834 & 0.881 & 0.926 & 0.974 & 1.02 \\
\hline Tetrahydrofuran & 0.610 & 0.648 & 0.684 & 0.721 & 0.758 & 0.794 \\
\hline 1,4-Dioxane & 0.484 & 0.523 & 0.562 & 0.602 & 0.644 & 0.683 \\
\hline tert-Butyl methyl ether & 2.30 & 2.41 & 2.52 & 2.62 & 2.72 & 2.83 \\
\hline tert-Butyl ethyl ether & 4.97 & 5.11 & 5.26 & 5.40 & 5.54 & 5.67 \\
\hline tert-Amyl methyl ether & 3.33 & 3.44 & 3.53 & 3.63 & 3.73 & 3.82 \\
\hline Diethyl ether & 2.30 & 2.39 & 2.47 & 2.56 & 2.64 & 2.72 \\
\hline Di- $n$-propyl ether & 5.93 & 5.99 & 6.04 & 6.08 & 6.13 & 6.19 \\
\hline Di-iso-propyl ether & 5.68 & 5.79 & 5.88 & 5.98 & 6.08 & 6.18 \\
\hline Di- $n$-butyl ether & 12.5 & 12.2 & 11.9 & 11.7 & 11.5 & 11.3 \\
\hline Acetone & 0.386 & 0.410 & 0.434 & 0.459 & 0.483 & 0.507 \\
\hline
\end{tabular}


Table 4 (Contd.)

\begin{tabular}{|c|c|c|c|c|c|c|}
\hline Solute & 318.15 & 328.15 & 338.15 & 348.15 & 358.15 & 368.15 \\
\hline Pentan-3-one & 0.651 & 0.697 & 0.741 & 0.788 & 0.833 & 0.879 \\
\hline Butanal & 0.675 & 0.711 & 0.747 & 0.782 & 0.818 & 0.852 \\
\hline Acetonitrile & 0.436 & 0.455 & 0.472 & 0.490 & 0.507 & 0.523 \\
\hline
\end{tabular}

230) mPa s, respectively. The diameter of the balls were $1.5 \mathrm{~mm}$ and $2.5 \mathrm{~mm}$ for the above viscosity ranges. The data obtained for the ILs are listed in Table $2 .^{22-24,26-28}$

\section{Apparatus and experimental procedure}

Experiments were performed using a Perkin Elmer Clarus 500 gas chromatograph equipped with a thermal conductivity detector (TCD). The data were collected and processed using the TotalChrom Workstation software. The column preparation and the packing method used in this work have been described in detail in our previous work. ${ }^{19,20}$ Glass columns of length $1 \mathrm{~m}$, with a $4 \mathrm{~mm}$ internal diameter were used. The solid support Chromosorb W/AW-DCMS 100/120 mesh was supplied by Sigma-Aldrich. Coating of the solid support material with the IL was performed by dispersing a certain portion of the IL in methanol, followed by evaporation of the solvent using a rotary evaporator. The masses of the stationary phase and of the solid support were weighed with a precision $\pm 0.0001 \mathrm{~g}$, achieving an uncertainty in the IL loading on the column in the order of $2 \times$ $10^{-4} \mathrm{mmol}$. The solvent loading on the column for 1-benzyl-3methylimidazolium dicyanamide was $45.1 \%$ and $49.7 \%$ mass percent, and for 1-benzyl-3-methylimidazolium bis $\{$ (trifluoromethyl)sulfonyl imide it was $45.0 \%$ and $50.7 \%$ mass percent. The large loading prevents possible residual adsorption of solute onto the column packing. Care was taken to ensure that the methanol was completely evaporated from the IL-coated solid support prior to column fabrication. Prior to each experiment, the column was conditioned by blowing hot carrier gas through it at a high flow rate $\left(\sim 2.0 \mathrm{~cm}^{3} \mathrm{~s}^{-1}\right)$ at $370 \mathrm{~K}$ for about $8 \mathrm{~h}$. The pressure drop $\left(P_{\mathrm{i}}-P_{\mathrm{o}}\right)$ was varied between 60 and $80 \mathrm{kPa}$ depending on the flow rate of the carrier gas. The inlet pressure, $P_{\mathrm{i}}$, was measured by a pressure gauge installed on the gas chromatograph with an uncertainty of $\pm 0.1 \mathrm{kPa}$ and the outlet pressure, $P_{\mathrm{o}}$, was measured using an Agilent Precision Gas Flow Meter having an uncertainty of $\pm 0.07 \mathrm{kPa}$. The mean column pressure, $\bar{p}$, inlet column pressure, $P_{\mathrm{i}}$, outlet column pressure, $P_{\mathrm{o}}$ and standard state of solutes at given temperatures and st. state are listed in Table $2 \mathrm{~S}$ in the ESI. $\dagger$

The carrier gas used was helium. The flow rate of carrier gas was determined using an Agilent precision gas flow meter which was placed at the outlet after the detector and had an uncertainty of $\pm 0.1 \mathrm{ml} \mathrm{min}{ }^{-1}$. The flow rate was set for a series of runs and was allowed to stabilize for at least $15 \mathrm{~min}$ before any $\gamma_{13}^{\infty}$ determinations were made. Solute injections ranged from 0.01 to $0.3 \mu \mathrm{l}$ and can be considered to be at "infinite dilution" on the column.

Temperature-dependent experiments were carried out in 10 K steps from (318.15 to 368.15) K. The temperature of the column was maintained constant to within $\pm 0.02 \mathrm{~K}$. At a given temperature, each experiment was repeated two to three times to establish reproducibility. Retention times were generally reproducible to within $10^{-3}$ to $10^{-2}$ min depending upon the temperature and the individual solute. At each temperature, values of the dead time, $t_{\mathrm{G}}$, equivalent to the retention time of a completely non-retained component were also measured. While our GC was equipped with a TCD detector, air was used as a non-retainable component. The estimated overall error in $\gamma_{13}^{\infty}$ was less than $3 \%$, taking into account the possible errors in determining the column loading, the retention times, and solute vapor pressure. The resultant activity coefficient values as a function of temperature are summarized in Tables 3 and 4 for $[\mathrm{BzMIM}][\mathrm{DCA}]$ and $[\mathrm{BzMIM}]\left[\mathrm{NTf}_{2}\right]$, respectively.

\section{Theoretical basis}

The equations developed by Everett ${ }^{30}$ and Cruickshank et al. ${ }^{31}$ were used in this work to calculate $\gamma_{13}^{\infty}$ for solutes in ILs:

$$
\ln \gamma_{13}^{\infty}=\ln \left(\frac{n_{3} R T}{V_{\mathrm{N}} P_{1}^{*}}\right)-\frac{P_{1}^{*}\left(B_{11}-V_{1}^{*}\right)}{R T}+\frac{P_{\mathrm{o}} J_{2}{ }^{3}\left(2 B_{12}-V_{1}^{\infty}\right)}{R T}
$$

In this expression, $n_{3}$ is the number of moles of solvent on the column packing, $R$ is the universal gas constant, $T$ is the column temperature, $V_{\mathrm{N}}$ denotes the net retention volume of the solute, $P_{1}^{*}$ is the saturated vapor pressure of the solute at temperature $T, B_{11}$ is the second virial coefficient of pure solute, $V_{1}^{*}$ is the molar volume of the solute, $P_{\mathrm{o}}$ is the outlet pressure, $P_{\mathrm{o}} J_{2}{ }^{3}$ is the mean column pressure, $B_{12}$ (where the subscript " 2 " refers to the carrier gas, in this case helium) is the mixed second virial coefficient of the solute and carrier gas, and $V_{1}^{\infty}$ is the partial molar volume of the solute at infinite dilution in the solvent. The thermophysical properties required in developing the activity coefficients at infinite dilution were calculated using equations and constants known from literature. ${ }^{32}$ The values of $B_{12}$ were calculated using the Tsonopolous equation. ${ }^{33}$ The pressure correction term, $J_{2}{ }^{3}$, is given by: 
Table 5 The experimental gas-liquid partition coefficients $K_{\mathrm{L}}$ for the solutes in ionic liquid [BzMIM][DCA] at different temperatures

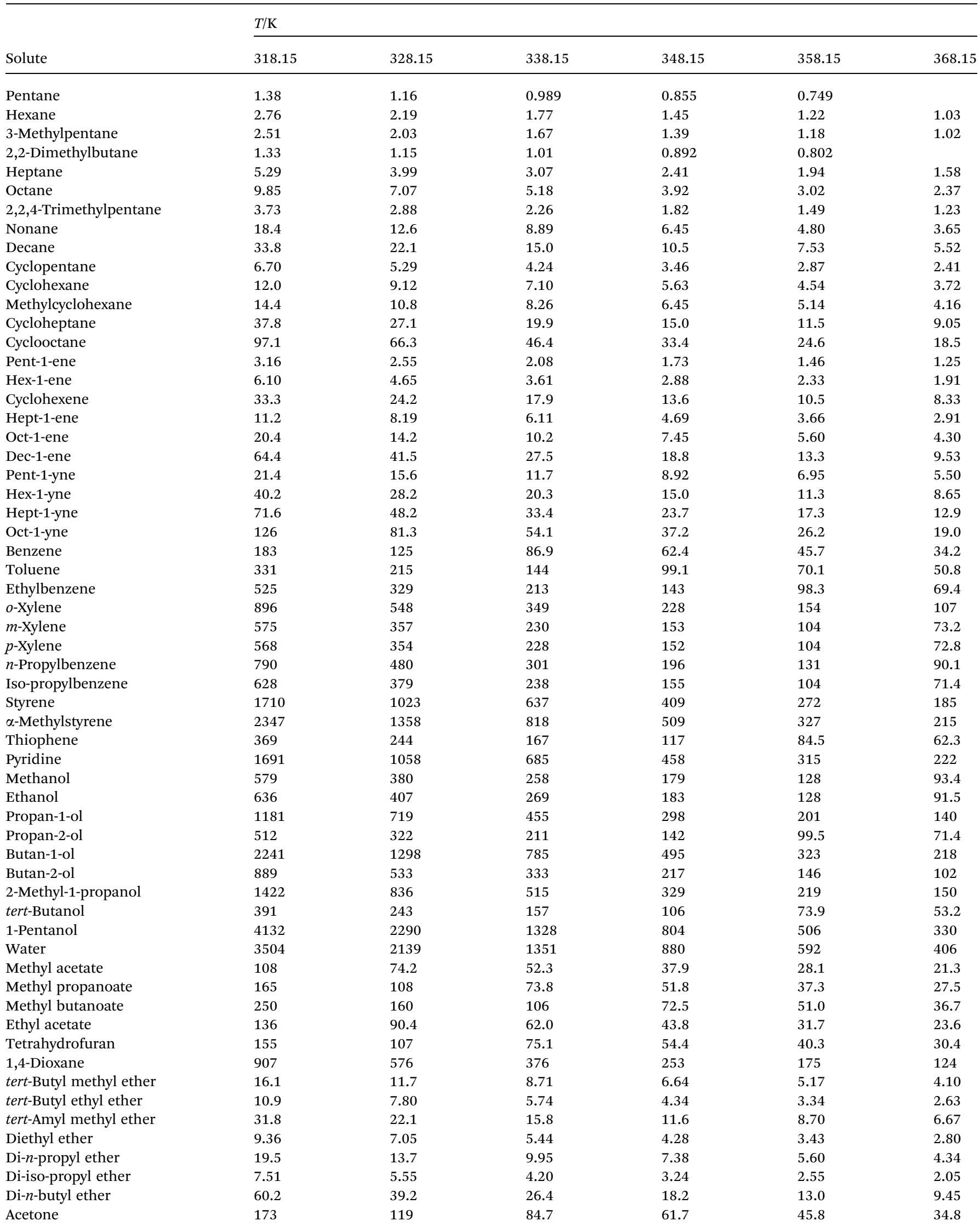




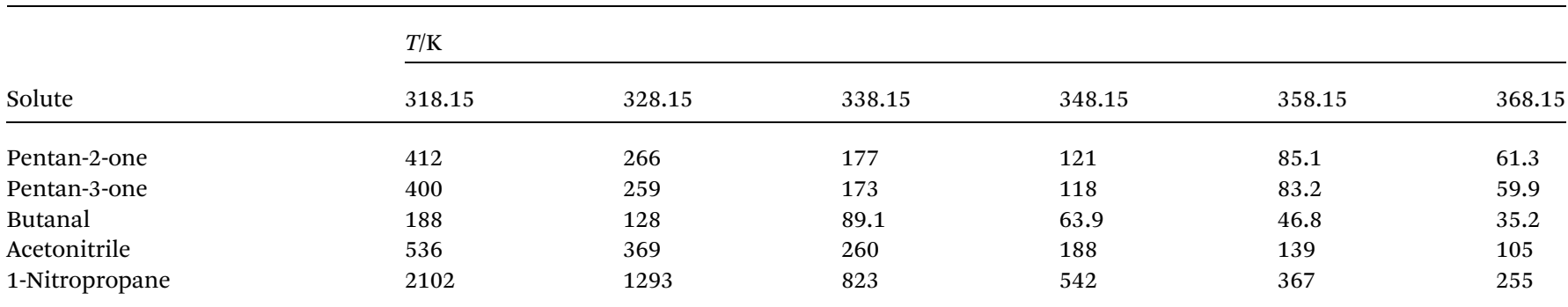

$$
J_{2}^{3}=\frac{2}{3} \frac{\left(P_{\mathrm{i}} / P_{\mathrm{o}}\right)^{3}-1}{\left(P_{\mathrm{i}} / P_{\mathrm{o}}\right)^{2}-1}
$$

The net retention volume of the solute, $V_{\mathrm{N}}$, is given by:

$$
V_{\mathrm{N}}=\left(J_{2}^{3}\right)^{-1} U_{\mathrm{o}}\left(t_{\mathrm{R}}-t_{\mathrm{G}}\right)
$$

where $t_{\mathrm{R}}$ and $t_{\mathrm{G}}$ are the retention times for the solute and an unretained gas, respectively, and $U_{\mathrm{o}}$ is the column outlet flow rate, taken from the apparatus.

While the activity coefficients at infinite dilution are determined as a function of temperature, $\ln \gamma_{13}^{\infty}$ can be split to its respective partial molar excess thermodynamic functions:

$$
\ln \gamma_{13}^{\infty}=\frac{\Delta H_{1}^{\mathrm{E}, \infty}}{R T}-\frac{\Delta S_{1}^{\mathrm{E}, \infty}}{R}
$$

Assuming that the temperature dependence follows a linear van't Hoff plot:

$$
\ln \gamma_{13}^{\infty}=a / T+b
$$

the partial molar excess enthalpy, $\Delta H_{1}^{\mathrm{E}, \infty}=R a$, at infinite dilution can be obtained from the slope.

The gas-liquid partition coefficient $K_{\mathrm{L}}=\left(c_{1}^{\mathrm{L}} / c_{1}^{\mathrm{G}}\right)$ for a solute partitioning between a carrier gas and the IL was calculated from the solute retention according to the following equation

$$
\ln \left(K_{\mathrm{L}}\right)=\ln \left(\frac{V_{\mathrm{N}} \rho_{3}}{m_{3}}\right)-\frac{P_{\mathrm{o}} J_{2}{ }^{3}\left(2 B_{12}-V_{1}^{\infty}\right)}{R T}
$$

In which $\rho_{3}$ is the density of the IL and $m_{3}$ is the mass of the IL and $V_{1}^{\infty}$ is the partial molar volume of the solute at infinite dilution.

\section{Results and discussion}

\section{Thermal and physico-chemical characteristic}

The DSC diagrams for [BzMIM] [DCA] and [BzMIM $]\left[\mathrm{NTf}_{2}\right]$ are shown in the ESI. $\uparrow$ Numerical data are included in Table 1. The temperatures of the glass phase transition $\left(T_{\mathrm{g}}\right.$, midpoint) are very close to each other and are $217.0 \pm 0.1 \mathrm{~K}$ ([BzMIM] [DCA]) and $216.9 \mathrm{~K} \pm 0.1\left([\mathrm{BzMIM}]\left[\mathrm{NTf}_{2}\right]\right)$. The literature values are 195.4 K (ref. 22) for [BzMIM][DCA] and $217 \mathrm{~K}$ (ref. 23), $215.8 \mathrm{~K}$ (ref. 24), 215.8 K (ref. 25) and 210.8 K (ref. 22) for [BzMIM][ $\left.\mathrm{NTf}_{2}\right]$.
The values of $\Delta C_{\mathrm{p}(\mathrm{g})}$ are in a range of $169.9 \pm 5 \mathrm{~J} \mathrm{~mol}^{-1} \mathrm{~K}^{-1}$ ([BzMIM][DCA]) to $199.5 \pm 5 \mathrm{~J} \mathrm{~mol}^{-1} \mathrm{~K}^{-1}[\mathrm{BzMIM}]\left[\mathrm{NTf}_{2}\right]$. It differs from values in ref. $31\left(\Delta C_{\mathrm{p}(\mathrm{g})} / \mathrm{J} \mathrm{mol}^{-1} \mathrm{~K}^{-1}=86.1\right)$ and is very close to ref. $30\left(\Delta C_{\mathrm{p}(\mathrm{g})} / \mathrm{J} \mathrm{mol}^{-1} \mathrm{~K}^{-1}=197\right)$ for [BzMIM] [NTf 2 .

Density and viscosity of [BzMIM][DCA] and [BzMIM] $\left.\mathrm{NTf}_{2}\right]$ were measured in this work as a function of temperature and are listed in Table 2 together with information from literature for the same ILs. The density measurements were carried out in the temperature range from (298.15 to 368.15$) \mathrm{K}$ at atmospheric pressure. The value obtained at $T=298.15 \mathrm{~K}$ is $1.15814 \mathrm{~g} \mathrm{~cm}^{-3}$ for [BzMIM][DCA] and $1.49098 \mathrm{~g} \mathrm{~cm}^{-3}$ for [BzMIM][ $\left.\mathrm{NTf}_{2}\right]$. The latter IL was measured in many laboratories, mostly at $T=$ 298.15 K (ref. 23-26 and 28) and $T=293.15 \mathrm{~K} .^{27}$ The density of [BzMIM] $\left[\mathrm{NTf}_{2}\right]$ in literature differs slightly from our data at higher temperatures. ${ }^{23}$ The mean percent deviation for six temperatures in a range from $298.15 \mathrm{~K}$ to $323.15 \mathrm{~K}$ between our values and published in ref. 23 is $-0.32 \%$, in ref. 24 (one point) is $-0.13 \%$ and in ref. 26 (one point) it is $-4.76 \%$. The other literature data are at different temperatures, thus it is difficult to compare the results. The viscosity at $T=298.15 \mathrm{~K}$ is $102 \mathrm{mPa} \mathrm{s}$ for [BzMIM] [DCA] and $133 \mathrm{mPa} \mathrm{s}$ for [BzMIM][ $\left.\mathrm{NTf}_{2}\right]$, which differ from the available literature values for [BzMIM] [NTf $]_{2}^{23,24}$ and is lower than those in other literature. ${ }^{34,36}$ The mean percent deviation for two temperatures $298.15 \mathrm{~K}$ and $308.15 \mathrm{~K}$ between our values and published in ref. 23 is $+17.5 \%$, in ref. 24 (one point) is $+6 \%$ and in ref. 26 (one point) it is $+54 \%$. Undoubtedly, the purity of the compound in different publications is responsible for such a differences.

The average values of $\gamma_{13}^{\infty}$ for the measured solutes in [BzMIM] [DCA] and [BzMIM][ $\left.\mathrm{NTf}_{2}\right]$, determined at six temperatures in a range from (318.15 to 368.15) $\mathrm{K}$ at atmospheric pressure are listed in Tables 3 and 4, respectively. Most of the virial coefficient values $B_{11}$ and $B_{12}$ and critical parameters for solutes used in this work were presented in our previous study. ${ }^{34}$ An analysis of the values of $\gamma_{13}^{\infty}$ shows large differences in possible interaction between a solute and the IL at infinite dilution. The data for [BzMIM] $\left[\mathrm{NTf}_{2}\right]$ shows almost five times lower values of $\gamma_{13}^{\infty}$ for the non-polar solutes in comparison with [BzMIM][DCA], which means much larger interaction between the $\left[\mathrm{NTf}_{2}\right]^{-}$anion with hydrocarbons than those of the [DCA $]^{-}$ anion. Aromatic hydrocarbons show much smaller differences; the values of $\gamma_{13}^{\infty}$ for benzene, toluene and others are only two times smaller for the $\left[\mathrm{NTf}_{2}\right]^{-}$anion. For polar substances, such as alcohols, the interaction between solute and the IL is similar 
Table 6 The experimental gas-liquid partition coefficients $K_{\mathrm{L}}$ for the solutes in ionic liquid [BzMIM][NTf $\mathrm{I}_{2}$ at different temperatures

\begin{tabular}{|c|c|c|c|c|c|c|}
\hline \multirow[b]{2}{*}{ Solute } & \multicolumn{6}{|l|}{$T / \mathrm{K}$} \\
\hline & 318.15 & 328.15 & 338.15 & 348.15 & 358.15 & 368.15 \\
\hline Hexane & 10.6 & 8.05 & 6.25 & 4.95 & 4.00 & 3.28 \\
\hline 3-Methylpentane & 10.1 & 7.66 & 5.96 & 4.73 & 3.83 & 3.15 \\
\hline 2,2-Dimethylbutane & 6.59 & 5.18 & 4.15 & 3.39 & 2.81 & 2.36 \\
\hline 2,2,4-Trimethylpentane & 20.9 & 15.2 & 11.3 & 8.64 & 6.73 & 5.34 \\
\hline Nonane & 87.2 & 57.5 & 39.3 & 27.6 & 20.0 & 14.8 \\
\hline Decane & 170 & 108 & 71.0 & 48.2 & 33.7 & 24.2 \\
\hline Cyclopentane & 14.8 & 11.4 & 8.91 & 7.10 & 5.77 & 4.75 \\
\hline Cyclohexane & 29.7 & 22.1 & 16.8 & 13.0 & 10.3 & 8.31 \\
\hline Methylcyclohexane & 42.3 & 30.5 & 22.6 & 17.1 & 13.2 & 10.4 \\
\hline Cyclohexene & 58.3 & 41.8 & 30.8 & 23.2 & 17.8 & 14.0 \\
\hline Hept-1-ene & 35.8 & 25.3 & 18.4 & 13.7 & 10.4 & 8.10 \\
\hline Oct-1-ene & 70.5 & 47.9 & 33.5 & 24.2 & 17.8 & 13.5 \\
\hline Dec-1-ene & 268 & 168 & 109 & 72.7 & 49.9 & 35.2 \\
\hline Pent-1-yne & 31.7 & 23.1 & 17.2 & 13.1 & 10.2 & 8.06 \\
\hline Hex-1-yne & 65.5 & 45.7 & 32.8 & 24.0 & 18.0 & 13.8 \\
\hline Hept-1-yne & 131 & 87.8 & 60.4 & 42.7 & 31.0 & 23.0 \\
\hline Oct-1-yne & 261 & 167 & 111 & 75.4 & 52.9 & 38.0 \\
\hline Benzene & 294 & 197 & 136 & 96.5 & 70.2 & 52.2 \\
\hline Toluene & 590 & 381 & 254 & 174 & 123 & 88.3 \\
\hline Ethylbenzene & 1067 & 661 & 424 & 281 & 191 & 133 \\
\hline$o$-Xylene & 1645 & 1003 & 634 & 415 & 279 & 193 \\
\hline Ethanol & 221 & 149 & 104 & 74.3 & 54.6 & 40.8 \\
\hline Propan-1-ol & 450 & 289 & 193 & 132 & 93.5 & 68.1 \\
\hline Propan-2-ol & 242 & 162 & 112 & 79.7 & 58.2 & 43.9 \\
\hline Butan-1-ol & 949 & 584 & 374 & 248 & 170 & 120 \\
\hline Butan-2-ol & 463 & 294 & 194 & 133 & 94.1 & 68.5 \\
\hline 2-Methyl-1-propanol & 626 & 391 & 256 & 173 & 121 & 87.3 \\
\hline tert-Butanol & 251 & 163 & 110 & 76.9 & 55.4 & 41.2 \\
\hline 1-Pentanol & 1989 & 1172 & 722 & 461 & 306 & 209 \\
\hline Water & 275 & 189 & 133 & 96.3 & 71.1 & 53.8 \\
\hline Methyl acetate & 226 & 153 & 106 & 76.5 & 56.1 & 42.2 \\
\hline Methyl propanoate & 404 & 262 & 175 & 121 & 86.1 & 62.5 \\
\hline Methyl butanoate & 687 & 434 & 283 & 191 & 132 & 94.2 \\
\hline Ethyl acetate & 363 & 237 & 159 & 111 & 78.6 & 57.4 \\
\hline Tetrahydrofuran & 295 & 199 & 138 & 98.7 & 72.1 & 53.8 \\
\hline 1,4-Dioxane & 1383 & 865 & 558 & 371 & 253 & 177 \\
\hline tert-Butyl methyl ether & 54.2 & 38.0 & 27.4 & 20.3 & 15.4 & 11.9 \\
\hline tert-Butyl ethyl ether & 45.8 & 31.7 & 22.5 & 16.5 & 12.3 & 9.40 \\
\hline tert-Amyl methyl ether & 109 & 74.1 & 51.8 & 37.2 & 27.3 & 20.5 \\
\hline Diethyl ether & 27.3 & 19.9 & 14.9 & 11.4 & 8.87 & 7.04 \\
\hline Di-n-propyl ether & 72.0 & 49.1 & 34.5 & 25.0 & 18.5 & 14.0 \\
\hline Di-iso-propyl ether & 34.9 & 24.6 & 17.8 & 13.2 & 9.96 & 7.67 \\
\hline Di- $n$-butyl ether & 266 & 168 & 110 & 74.6 & 51.9 & 37.0 \\
\hline Acetone & 340 & 232 & 162 & 117 & 85.7 & 64.3 \\
\hline Pentan-2-one & 1072 & 675 & 440 & 296 & 204 & 145 \\
\hline
\end{tabular}


Table 6 (Contd.)

\begin{tabular}{|c|c|c|c|c|c|c|}
\hline \multirow[b]{2}{*}{ Solute } & \multicolumn{6}{|l|}{$T / \mathrm{K}$} \\
\hline & 318.15 & 328.15 & 338.15 & 348.15 & 358.15 & 368.15 \\
\hline Pentan-3-one & 1049 & 661 & 430 & 288 & 198 & 139 \\
\hline Butanal & 371 & 249 & 172 & 122 & 88.8 & 66.1 \\
\hline Acetonitrile & 732 & 497 & 346 & 247 & 181 & 135 \\
\hline 1-Nitropropane & 3265 & 2007 & 1276 & 838 & 566 & 394 \\
\hline
\end{tabular}

and for water it is much lower for the $\left[\mathrm{NTf}_{2}\right]^{-}$anion. This confirms the common information about hydrophobicity of $\left[\mathrm{NTf}_{2}\right]^{-}$- based ILs which is the most important for consideration for the three separation cases, viz. hexane/hex-1-ene, cyclohexane/cyclohexene and ethylbenzene/styrene. The values for the mentioned solutes at $T=328.15 \mathrm{~K}$ : for hexane $\gamma_{13}^{\infty}=95.4$ or $\gamma_{13}^{\infty}=17.6$ in [BzMIM] [DCA] and [BzMIM] $\left.\mathrm{NTf}_{2}\right]$, respectively; for hex-1-ene $\gamma_{13}^{\infty}=38.1$ or $\gamma_{13}^{\infty}=9.27$ in [BzMIM][DCA] and [BzMIM] $\left.\mathrm{NTf}_{2}\right]$, respectively; for cyclohexane $\gamma_{13}^{\infty}=33.5$ or $\gamma_{13}^{\infty}=$ 9.39 in [BzMIM] [DCA] and [BzMIM] $\left.\mathrm{NTf}_{2}\right]$, respectively; for cyclohexene $\gamma_{13}^{\infty}=13.6$ or $\gamma_{13}^{\infty}=5.31$ in [BzMIM][DCA] and [BzMIM] [NTf $]$, respectively; for ethylbenzene $\gamma_{13}^{\infty}=6.71$ or $\gamma_{13}^{\infty}=2.26$ in [BzMIM] [DCA] and [BzMIM] $\left[\mathrm{NTf}_{2}\right]$, respectively; and for styrene $\gamma_{13}^{\infty}=3.11$ or $\gamma_{13}^{\infty}=1.32$ in [BzMIM][DCA] and [BzMIM] $\left[\mathrm{NTf}_{2}\right]$, respectively. For all these solutes, the interaction with the IL is almost three times larger for [BzMIM] [ $\left.\mathrm{NTf}_{2}\right]$. Thus, the selectivities for separation may be expected to not be very different from each other for the two ILs.

The global analysis drawn from Tables 3 and 4 shows that the $\gamma_{13}^{\infty}$ values increase with the alkyl chain length in a series of alkanes, cycloalkanes, alkenes, alkynes, aromatic hydrocarbons (increasing radicals), alcohols, ethers, and ketones, which is an indication of the decrease of interactions between the solute and the IL at infinite dilution. Furthermore, despite the lower number of alkyl chains, the higher measured retention time is an evident observation of the decrease of the $\gamma_{13}^{\infty}$ values, and of an increase in the interactions between the IL and solute. The lowest values of $\gamma_{13}^{\infty}$ at all temperatures (the strongest interaction) in [BzMIM][DCA] are observed for water $\left(\gamma_{13}^{\infty}=0.387\right)$, methanol $\left(\gamma_{13}^{\infty}=0.511\right)$, ethanol $\left(\gamma_{13}^{\infty}=0.872\right)$, acetonitrile $\left(\gamma_{13}^{\infty}=0.903\right)$, and pyridine $\left(\gamma_{13}^{\infty}=1.03\right)$ at $T=328.15 \mathrm{~K}$. The lowest values of $\gamma_{13}^{\infty}$ at all temperatures (the largest interaction) in $[\mathrm{BzMIM}]\left[\mathrm{NTf}_{2}\right]$ are observed for acetone $\left(\gamma_{13}^{\infty}=0.410\right)$, acetonitrile $\left(\gamma_{13}^{\infty}=0.455\right), 1,4$-dioxane $\left(\gamma_{13}^{\infty}=0.523\right)$, tetrahydrofuran $\left(\gamma_{13}^{\infty}=0.648\right), 1$-nitropropane $\left(\gamma_{13}^{\infty}=0.692\right)$, and pentan-2-one $\left(\gamma_{13}^{\infty}=0.693\right)$ at $T=328.15 \mathrm{~K}$. As can be seen, the strongest interactions for the two different anions is observed for different solutes. Only acetonitrile is common for the two ILs, with the value two times larger in [BzMIM] [DCA] than that in [BzMIM] [NTf ${ }_{2}$.

The largest values of $\gamma_{13}^{\infty}$ provide the initial information about the lower interactions. For [BzMIM][DCA] it may be observed for decane $\left(\gamma_{13}^{\infty}=509\right)$, dec-1-ene $\left(\gamma_{13}^{\infty}=220\right)$ and di- $n$ butyl ether $\left(\gamma_{13}^{\infty}=77.2\right)$ at $T=328.15 \mathrm{~K}$. The largest values of $\gamma_{13}^{\infty}$ for [BzMIM] $\left[\mathrm{NTf}_{2}\right]$ are observed for decane $\left(\gamma_{13}^{\infty}=70.7\right)$ and dec-1-ene $\left(\gamma_{13}^{\infty}=36.8\right)$ at $T=328.15 \mathrm{~K}$. These latter values are appreciably lower than those for [BzMIM][DCA].

An interesting feature worth noting is a comparison to two ILs, $[\mathrm{AMIM}][\mathrm{DCA}]^{16}$ and $[\mathrm{AMIM}]\left[\mathrm{NTf}_{2}\right]^{20}$ which show the same relations in the interactions for the measured solutes. Strong interactions for [AMIM][DCA] were observed with water and methanol $\left(\gamma_{13}^{\infty}=0.341, \gamma_{13}^{\infty}=0.505\right.$ at $\left.T=328.15 \mathrm{~K}\right)$, all alcohols as well as with thiophene, pyridine, 1,4-dioxane, acetone, acetonitrile, and 1-nitropropane with $\gamma_{13}^{\infty}<2$ at $T=328.15 \mathrm{~K}^{\mathbf{1 6}}$ The $\gamma_{13}^{\infty}$ data for the $\left[\mathrm{NTf}_{2}\right]^{-}$-based ILs show much smaller interactions with water and alcohols. Nonetheless, the lower values of $\gamma_{13}^{\infty}$ for polar solutes such as benzene, thiophene, pyridine, and 1-nitropropane for the $\left[\mathrm{NTf}_{2}\right]^{-}$-based ILs suggest the high potential for the extraction of these compounds from alkanes, which is important in petrochemical processes, e.g. desulphurization and denitrification of fuels. The hydrocarbons, such as alkanes, alkenes and alkynes reveal much lower values of $\gamma_{13}^{\infty}$ in $[\mathrm{AMIM}]\left[\mathrm{NTf}_{2}\right]^{20}$ than those observed earlier for [AMIM][DCA $]^{16}\left(\gamma_{13}^{\infty}<100\right.$ at $\left.T=328.15 \mathrm{~K}\right)$. The $\gamma_{13}^{\infty}$ values in [AMIM] $\left[\mathrm{NTf}_{2}\right]$ were $\gamma_{13}^{\infty}=20.8$ and $\gamma_{13}^{\infty}=10.7$ at $T=328.15 \mathrm{~K}$ for hexane and hex-1-ene, respectively.

The experimental $\gamma_{13}^{\infty}$ values exhibit diverse temperature dependences corresponding on both endothermic and exothermic effects accompanying the interactions of solutes with the IL. The $\gamma_{13}^{\infty}$ values decrease with an increasing temperature for alkanes, alkenes, cycloalkanes and cycloalkenes (see Fig. 2S and 3S in ESI $\dagger$ ). The opposite influence of temperature is presented for alkynes (see Fig. 3S in ESI $\dagger$ ) and for aromatic hydrocarbons (see Fig. $4 \mathrm{~S}$ in $\mathrm{ESI} \dagger$ ). Only for the case of alcohols and water in $[\mathrm{BzMIM}]\left[\mathrm{NTf}_{2}\right]$ do the $\gamma_{13}^{\infty}$ values decrease with an increasing temperature (see Fig. $5 \mathrm{Sb}$ in ESI $\dagger$ ). For alcohols in [BzMIM][DCA] (see Fig. 5Sa in ESI $\dagger$ ) and most of the ethers (see Fig. 6S in ESI $\dagger$ ), esters, tetrahydrofuran, 1,4-dioxane, thiophene (see Fig. 7S in ESI $\dagger$ ) and ketones, as well as 1-nitropropane (see Fig. 8S in ESI $\dagger$ ) there is an increase in $\gamma_{13}^{\infty}$ values with an increasing temperature. The diagrams mentioned above show the plot of the natural logarithm of the $\gamma_{13}^{\infty}$ as a function of the inverse absolute temperature for all investigated solutes.

The gas-liquid partition coefficient, $K_{\mathrm{L}}$, calculated from eqn (6) is an important property of the IL. This property shows the suitability of the IL for particular application in extraction. The data for $[\mathrm{BzMIM}][\mathrm{DCA}]$ and $[\mathrm{BzMIM}]\left[\mathrm{NTf}_{2}\right]$ are listed in Tables 5 and 6. By inspection of these tables one can see that the lowest values are observed for alkanes $\left(K_{\mathrm{L}}=2.19\right.$ at $T=328.15 \mathrm{~K}$ in $[\mathrm{BzMIM}][\mathrm{DCA}])$, cycloalkanes, cylcloalkenes, alkenes, alkynes 
Table 7 Limiting partial molar excess Gibbs energies, $\Delta G_{1}^{E, \infty}$ enthalpies $\Delta H_{1}^{E, \infty}$ and entropies $T_{\text {ref }} \Delta S_{1}^{E, \infty}$ for the solutes in investigated ionic liquids $[\mathrm{BzMIM}][\mathrm{DCA}]$ and $[\mathrm{BzMIM}]\left[\mathrm{NTf} \mathrm{f}_{2}\right]$ at the reference temperature $T_{\text {ref }}=328.15 \mathrm{~K}$

\begin{tabular}{|c|c|c|c|c|c|c|}
\hline \multirow[b]{2}{*}{ Solute } & \multicolumn{3}{|l|}{$[\mathrm{BzMIM}][\mathrm{DCA}]$} & \multicolumn{3}{|l|}{$[\mathrm{BzMIM}]\left[\mathrm{NTf}_{2}\right]$} \\
\hline & $\Delta G_{1}^{\mathrm{E}, \infty} / \mathrm{kJ} \mathrm{mol}^{-1}$ & $\Delta H_{1}^{\mathrm{E}, \infty} / \mathrm{kJ} \mathrm{mol}^{-1}$ & $T_{\mathrm{ref}} \Delta S_{1}^{\mathrm{E}, \infty} / \mathrm{kJ} \mathrm{mol}^{-1}$ & $\Delta G_{1}^{\mathrm{E}, \infty} / \mathrm{kJ} \mathrm{mol}^{-1}$ & $\Delta H_{1}^{\mathrm{E}, \infty} / \mathrm{kJ} \mathrm{mol}^{-1}$ & $T_{\mathrm{ref}} \Delta S_{1}^{\mathrm{E}, \infty} / \mathrm{kJ} \mathrm{mol}^{-1}$ \\
\hline Pentane & 11.4 & 8.20 & -3.19 & 6.98 & 4.03 & -2.95 \\
\hline Hexane & 12.4 & 7.77 & -4.67 & 7.82 & 4.15 & -3.67 \\
\hline 3-Methylpentane & 12.2 & 8.41 & -3.75 & 7.46 & 3.39 & -4.07 \\
\hline 2,2-Dimethylbutane & 12.6 & 11.69 & -0.90 & 7.41 & 3.50 & -3.90 \\
\hline Heptane & 13.6 & 8.40 & -5.16 & 8.76 & 4.80 & -3.96 \\
\hline Octane & 14.7 & 8.74 & -5.98 & 9.72 & 6.21 & -3.52 \\
\hline 2,2,4-Trimethylpentane & 14.4 & 9.10 & -5.26 & 8.77 & 4.14 & -4.63 \\
\hline Nonane & 15.8 & 9.67 & -6.17 & 10.6 & 6.63 & -4.00 \\
\hline Decane & 17.0 & 10.45 & -6.55 & 11.6 & 7.77 & -3.85 \\
\hline Cyclopentane & 8.31 & 4.75 & -3.56 & 5.15 & 2.55 & -2.60 \\
\hline Cyclohexane & 9.58 & 5.99 & -3.59 & 6.11 & 3.98 & -2.13 \\
\hline Methylcyclohexane & 10.9 & 6.87 & -4.02 & 7.00 & 3.82 & -3.17 \\
\hline Cycloheptane & 10.1 & 6.12 & -4.01 & 6.80 & 4.11 & -2.69 \\
\hline Cyclooctane & 10.9 & 6.61 & -4.27 & 7.50 & 5.07 & -2.43 \\
\hline Pent-1-ene & 8.75 & 3.63 & -5.12 & 5.15 & 0.70 & -4.45 \\
\hline Hex-1-ene & 9.93 & 4.36 & -5.57 & 6.08 & 2.25 & -3.83 \\
\hline Cyclohexene & 7.12 & 2.03 & -5.10 & 4.56 & 1.29 & -3.27 \\
\hline Hept-1-ene & 11.1 & 4.61 & -6.50 & 6.98 & 2.03 & -4.95 \\
\hline Oct-1-ene & 12.3 & 5.28 & -7.07 & 7.98 & 3.50 & -4.47 \\
\hline Dec-1-ene & 14.7 & 6.79 & -7.93 & 9.84 & 4.47 & -5.37 \\
\hline Pent-1-yne & 4.58 & -2.55 & -7.13 & 2.46 & -2.72 & -5.18 \\
\hline Hex-1-yne & 5.71 & -1.69 & -7.40 & 3.34 & -2.04 & -5.38 \\
\hline Hept-1-yne & 6.96 & -0.85 & -7.81 & 4.26 & -1.32 & -5.58 \\
\hline Oct-1-yne & 8.20 & 0.22 & -7.98 & 5.17 & -0.41 & -5.58 \\
\hline Benzene & 2.43 & -3.21 & -5.64 & 0.13 & -4.13 & -4.26 \\
\hline Toluene & 3.82 & -2.96 & -6.78 & 1.20 & -3.42 & -4.61 \\
\hline Ethylbenzene & 5.19 & -1.85 & -7.04 & 2.22 & -2.91 & -5.13 \\
\hline$o$-Xylene & 4.66 & -2.44 & -7.10 & 1.95 & -2.73 & -4.67 \\
\hline$m$-Xylene & 5.29 & -2.16 & -7.45 & 2.25 & -3.39 & -5.64 \\
\hline$p$-Xylene & 5.21 & -2.23 & -7.44 & 2.27 & -3.32 & -5.60 \\
\hline$n$-Propylbenzene & 6.54 & -1.13 & -7.68 & 3.22 & -2.45 & -5.67 \\
\hline Iso-propylbenzene & 6.52 & -1.93 & -8.44 & 3.16 & -2.37 & -5.54 \\
\hline Styrene & 3.10 & -3.80 & -6.90 & 0.76 & -4.53 & -5.29 \\
\hline$\alpha$-Methylstyrene & 4.41 & -4.65 & -9.06 & 1.86 & -4.93 & -6.79 \\
\hline Thiophene & 0.99 & -4.33 & -5.32 & -0.29 & -3.82 & -3.53 \\
\hline Pyridine & 0.081 & -3.87 & -3.96 & -1.83 & -4.39 & -2.56 \\
\hline Methanol & -1.83 & -1.36 & 0.48 & 0.67 & 4.37 & 3.70 \\
\hline Ethanol & -0.37 & 0.14 & 0.52 & 1.30 & 5.14 & 3.84 \\
\hline Propan-1-ol & 0.40 & 0.40 & 0.00 & 1.84 & 5.14 & 3.30 \\
\hline Propan-2-ol & 0.82 & 1.42 & 0.60 & 1.63 & 6.57 & 4.94 \\
\hline Butan-1-ol & 1.38 & 1.06 & -0.32 & 2.50 & 6.27 & 3.77 \\
\hline Butan-2-ol & 1.53 & 0.55 & -0.97 & 2.09 & 5.61 & 3.52 \\
\hline 2-Methyl-1-propanol & 1.42 & 1.71 & 0.29 & 2.43 & 7.20 & 4.76 \\
\hline tert-Butanol & 1.60 & 0.62 & -0.99 & 1.62 & 4.33 & 2.71 \\
\hline 1-Pentanol & 2.20 & 0.59 & -1.61 & 2.97 & 6.04 & 3.07 \\
\hline Water & -2.59 & -2.06 & 0.53 & 2.97 & 8.16 & 5.19 \\
\hline Methyl acetate & 1.81 & -3.98 & -5.79 & -1.23 & -4.91 & -3.68 \\
\hline Methyl propanoate & 2.90 & -3.82 & -6.72 & -0.56 & -5.20 & -4.64 \\
\hline Methyl butanoate & 4.13 & -2.74 & -6.87 & 0.36 & -4.03 & -4.39 \\
\hline Ethyl acetate & 3.19 & -3.26 & -6.45 & -0.50 & -5.03 & -4.53 \\
\hline Tetrahydrofuran & 1.57 & -3.78 & -5.36 & -1.18 & -5.13 & -3.95 \\
\hline 1,4-Dioxane & 0.40 & -5.56 & -5.96 & -1.77 & -6.72 & -4.95 \\
\hline tert-Butyl methyl ether & 6.66 & -1.21 & -7.87 & 2.40 & -4.03 & -6.43 \\
\hline tert-Butyl ethyl ether & 9.33 & 0.57 & -8.76 & 4.45 & -2.59 & -7.04 \\
\hline tert-Amyl methyl ether & 7.73 & -0.53 & -8.26 & 3.37 & -2.67 & -6.04 \\
\hline Diethyl ether & 6.27 & -0.49 & -6.75 & 2.38 & -3.30 & -5.68 \\
\hline Di- $n$-propyl ether & 9.42 & 1.78 & -7.65 & 4.88 & -0.80 & -5.68 \\
\hline Di-iso-propyl ether & 9.91 & 2.49 & -7.42 & 4.79 & -1.62 & -6.41 \\
\hline Di- $n$-butyl ether & 11.9 & 4.17 & -7.69 & 6.82 & 1.91 & -4.91 \\
\hline Acetone & 0.43 & -4.15 & -4.58 & -2.43 & -5.33 & -2.89 \\
\hline
\end{tabular}


Table 7 (Contd.)

\begin{tabular}{|c|c|c|c|c|c|c|}
\hline \multirow[b]{2}{*}{ Solute } & \multicolumn{3}{|l|}{$\underline{\text { BzMIM }][\mathrm{DCA}]}$} & \multicolumn{3}{|l|}{$\underline{\mathrm{BzMIM}]}\left[\mathrm{NTf}_{2}\right]$} \\
\hline & $\Delta G_{1}^{\mathrm{E}, \infty} / \mathrm{kJ} \mathrm{mol}^{-1}$ & $\Delta H_{1}^{\mathrm{E}, \infty} / \mathrm{kJ} \mathrm{mol}^{-1}$ & $T_{\mathrm{ref}} \Delta S_{1}^{\mathrm{E}, \infty} / \mathrm{kJ} \mathrm{mol}^{-1}$ & $\Delta G_{1}^{\mathrm{E}, \infty} / \mathrm{kJ} \mathrm{mol}^{-1}$ & $\Delta H_{1}^{\mathrm{E}, \infty} / \mathrm{kJ} \mathrm{mol}^{-1}$ & $T_{\mathrm{ref}} \Delta S_{1}^{\mathrm{E}, \infty} / \mathrm{kJ} \mathrm{mol}^{-1}$ \\
\hline Pentan-2-one & 2.60 & -3.45 & -6.04 & -1.00 & -5.25 & -4.25 \\
\hline Pentan-3-one & 2.63 & -3.59 & -6.22 & -0.98 & -5.86 & -4.87 \\
\hline Butanal & 1.95 & -3.63 & -5.57 & -0.93 & -4.53 & -3.60 \\
\hline Acetonitrile & -0.28 & -2.45 & -2.17 & -2.15 & -3.53 & -1.39 \\
\hline 1-Nitropropane & 1.25 & -2.84 & -4.09 & -1.00 & -2.93 & -1.92 \\
\hline
\end{tabular}

and ethers, especially for diethyl ether in [BzMIM] [DCA] $\left(K_{\mathrm{L}}=\right.$ 7.05 at $T=328.15 \mathrm{~K})$. The large values of $K_{\mathrm{L}}$ are observed for 1pentanol $\left(K_{\mathrm{L}}=2290\right.$ at $T=328.15 \mathrm{~K}$ in $\left.[\mathrm{BzMIM}][\mathrm{DCA}]\right)$, water $\left(K_{\mathrm{L}}\right.$ $=2139$ at $T=328.15 \mathrm{~K}$ in [BzMIM] [DCA]) and $\alpha$-methylstyrene $\left(K_{\mathrm{L}}=1358\right.$ at $T=328.15 \mathrm{~K}$ in $[\mathrm{BzMIM}][\mathrm{DCA}]$ and $K_{\mathrm{L}}=2336$ at $T$ $=328.15 \mathrm{~K}$ in $\left.[\mathrm{BzMIM}]\left[\mathrm{NTf}_{2}\right]\right)$ as well as for 1-nitropropane $\left(K_{\mathrm{L}}=\right.$ 2007 at $T=328.15 \mathrm{~K}$ in [BzMIM] [ $\left.\mathrm{NTf}_{2}\right]$ ). These values are much lower than those observed for $[\mathrm{AMIM}][\mathrm{DCA}]^{16}$ and similar to those observed for $[\mathrm{AMIM}]\left[\mathrm{NTf}_{2}\right]^{20}$ The high $K_{\mathrm{L}}$ value corresponds to a large affinity of the solute to the liquid phase. The $K_{\mathrm{L}}$ value increases with a decrease of temperature and with an increase of the alkane chain length for alkanes, alkenes, alkynes, cycloalkanes, alcohols, esters and ethers. The $K_{\mathrm{L}}$ values increase with an increase of the radicals in the aromatic compounds.

Table 7 lists the partial molar excess Gibbs energies, $\Delta G_{1}^{\mathrm{E}, \infty}$, at infinite dilution, the molar excess enthalpies, $\Delta H_{1}^{\mathrm{E}, \infty}$, at infinite dilution, and the partial molar excess entropies at infinite dilution, $T_{\text {ref }} \Delta S_{1}^{\mathrm{E}, \infty}$, for all the solutes studied in $[\mathrm{BzMIM}][\mathrm{DCA}]$ and $[\mathrm{BzMIM}]\left[\mathrm{NTf}_{2}\right]$, respectively, at a reference temperature $T=328.15 \mathrm{~K}$. These thermodynamic functions specify the interaction between solute and the IL and are an important consideration in determining the suitability of the IL for extraction. The $\Delta G_{1}^{\mathrm{E}, \infty}$ was calculated from the temperature dependence of $\gamma_{13}^{\infty}$. The values of $\Delta G_{1}^{\mathrm{E}, \infty}$ are positive for all solutes except methanol, ethanol, water and acetonitrile in [BzMIM][DCA], as well as thiophene, pyridine, esters, tetrahydrofuran, 1,4-dioxane, ketones, acetonitrile and 1-nitropropane in $[\mathrm{BzMIM}]\left[\mathrm{NTf}_{2}\right]$. This is similar to the earlier measured data for $[\mathrm{AMIM}][\mathrm{DCA}]^{16}$ and $[\mathrm{AMIM}]\left[\mathrm{NTf}_{2}\right] .{ }^{20}$ The infinite dilution activity coefficient values are lower than one for these solutes, i.e. $\gamma_{13}^{\infty}<1$, which corresponds to the (IL + solute) binary system with negative deviations from Raoult's law. The largest negative value of $\Delta G_{1}^{\mathrm{E}, \infty}$ was observed for water in [BzMIM] [DCA] $(-2.59$ $\left.\mathrm{kJ} \mathrm{mol}^{-1}\right)$ and for acetone in [BzMIM] $\left[\mathrm{NTf}_{2}\right]\left(-2.43 \mathrm{~kJ} \mathrm{~mol}^{-1}\right)$. For the remaining solutes, including hexane $\left(\Delta G_{1}^{\mathrm{E}, \infty}=12.48 \mathrm{~kJ}\right.$ $\mathrm{mol}^{-1}$ in [BzMIM][DCA]) and hex-1-ene $\left(\Delta G_{1}^{\mathrm{E}, \infty}=9.93 \mathrm{~kJ} \mathrm{~mol}^{-1}\right.$ in [BzMIM][DCA]), positive deviations from ideality are obtained. The large positive values are observed for long-chain alkanes in [BzMIM][DCA], which indicates that the solute-IL interaction is not strong and limited miscibility is possible in the liquid phase.

The partial excess molar enthalpies at infinite dilution, $\Delta H_{1}^{\mathrm{E}, \infty}$, determined from the Gibbs-Helmholtz equation exhibit negative values for alkynes, aromatic hydrocarbons, esters some ethers, ketones and 1-nitropropane for both ILs. For these solutes relatively strong energetic solute-solvent interactions are observed. Additionally, there are negative $\Delta H_{1}^{\mathrm{E}, \infty}$ values for [BzMIM][DCA] with water and methanol. As expected, the $\left[\mathrm{NTf}_{2}\right]^{-}$, the hydrophobic anion of the IL used in this work, exhibits possible $\pi-\pi$, or $n-\pi$ interactions with most of the solutes, which leads to negative values of $\Delta H_{1}^{\mathrm{E}, \infty}$. For the other solutes, no particular affinity between the IL and solute molecule is expected. Thus for aliphatic hydrocarbons, the endothermic interaction, resulting from the energetic weakness of their interaction with the IL is observed.

The partial excess molar entropies at infinite dilution, $T_{\text {ref }^{-}}$ $\Delta S_{1}^{\mathrm{E}, \infty}$, are small and negative for all solutes studied, excluding alcohols and water in [BzMIM] $\left.\mathrm{NTf}_{2}\right]$, and excluding a few alcohols and water in [BzMIM][DCA]. The solution of the majority of the solutes in both ILs is accompanied by entropy losses, which may suggest that the solute molecule arranges itself in the IL structure. The most positive value of the $T_{\text {ref }}{ }^{-}$ $\Delta S_{1}^{\mathrm{E}, \infty}$ term was observed for water, $0.53 \mathrm{~kJ} \mathrm{~mol}^{-1}$ and $5.19 \mathrm{~kJ}$ $\mathrm{mol}^{-1}$ for [BzMIM][DCA] and [BzMIM] $\left[\mathrm{NTf}_{2}\right]$, respectively, whilst for the previously measured [AMIM][DCA $]^{16}$ it was 11.79 $\mathrm{kJ} \mathrm{mol}^{-1}$.

\section{Separation of hexane/hex-1-ene, cyclohexane/cyclohexene and ethylbenzene/styrene}

To analyze the performance of the [BzMIM][DCA] and [BzMIM] $\left[\mathrm{NTf}_{2}\right]$ ILs as extraction solvents for the chosen separation processes, the characteristic parameters for the separation, the selectivity $\left(S_{12}^{\infty}=\gamma_{1}^{\infty} / \gamma_{2}^{\infty}\right)$ and the capacity $\left(k_{2}^{\infty}=1 / \gamma_{2}^{\infty}\right)$ were calculated from the experimental activity coefficients at infinite dilution values. The results are listed in Table 8 for both ILs for the three separation cases: hexane (1)/hex-1-ene (2), cyclohexane (1)/cyclohexene (2), and ethylbenzene (1)/styrene (2) at $T=$ $328.15 \mathrm{~K}$, along with literature data for ILs with the same anions, $[\mathrm{DCA}]^{-}$and $\left[\mathrm{NTf}_{2}\right]^{-}$. To study the effect of the anion and cation structure on the extractive properties, the selectivity of 65 ILs have been compared to [BzMIM] [DCA] and [BzMIM] $\left[\mathrm{NTf}_{2}\right]$ at the same temperature. In addition, to evaluate the potential of the ILs to be used at industrial scale, a comparison of capacity has also been performed.

Even though the experimental data present large discrepancies among different literature sources, one can conclude that the selectivities for the hexane (1)/hex-1-ene (2) separation, obtained with benzyl-based ILs is quite high with the best value for the imidazolium-based IL, [AMIM] [DCA $]\left(S_{12}^{\infty}=2.51\right) .{ }^{16}$ The 
Table 8 Selectivities, $S_{12}^{\infty}$, and capacities, $k_{2}^{\infty}$ for hexane/hexane, cyclohexane/cyclohexene and ethylbenzene/styrene separation problems for $[\mathrm{DCA}]^{-}$and $\left[\mathrm{NTf}_{2}\right]^{-}$based ionic liquids at $T=328.15 \mathrm{~K}$

\begin{tabular}{|c|c|c|c|c|c|c|c|}
\hline \multirow[b]{2}{*}{ Ionic liquid abbreviation } & \multicolumn{3}{|l|}{$S_{12}^{\infty}$} & \multicolumn{3}{|l|}{$k_{12}^{\infty}$} & \multirow[b]{2}{*}{ Ref. } \\
\hline & Hexane/hexene & Cyclohexane/cyclohexene & Ethylbenzene/styrene & Hexene & Cyclohexene & Styrene & \\
\hline [BzMIM] $][\mathrm{DCA}]$ & 2.50 & 2.46 & 2.16 & 0.03 & 0.07 & 0.32 & This work \\
\hline$[$ BzMIM] $]\left[\right.$ NTf $\left._{2}\right]$ & 1.90 & 1.77 & 1.71 & 0.11 & 0.19 & 0.76 & This work \\
\hline$[\mathrm{EMIM}][\mathrm{DCA}]$ & 2.46 & - & - & 0.02 & - & - & 17 \\
\hline$[\mathrm{AMIM}][\mathrm{DCA}]$ & 2.51 & 2.51 & 2.24 & 0.02 & 0.05 & 0.25 & 16 \\
\hline$[\mathrm{BMIM}][\mathrm{DCA}]$ & 2.29 & 2.19 & 2.14 & 0.04 & 0.09 & 0.44 & 15 \\
\hline$[\mathrm{BMPY}][\mathrm{DCA}]$ & 2.34 & 2.32 & 2.31 & 0.05 & 0.12 & 0.72 & 35 \\
\hline$[\mathrm{CPMIM}][\mathrm{DCA}]$ & 2.30 & - & - & 0.02 & - & - & 18 \\
\hline [CPMMIM $][\mathrm{DCA}]$ & 2.16 & - & - & 0.04 & - & - & 18 \\
\hline$\left[\mathrm{N}-\mathrm{C}_{3} \mathrm{OHMIM}\right][\mathrm{DCA}]$ & 2.79 & - & - & 0.01 & - & - & 36 \\
\hline$[\mathrm{MMIM}]\left[\mathrm{NTf}_{2}\right]$ & 2.10 & - & - & 0.07 & - & - & 37 \\
\hline$[\mathrm{EMIM}]\left[\mathrm{NTf}_{2}\right]$ & 2.02 & 1.81 & - & 0.09 & 0.14 & - & 37 \\
\hline$[\mathrm{EMIM}]\left[\mathrm{NTf}_{2}\right]$ & 3.02 & - & - & 0.13 & - & - & 38 \\
\hline$[\mathrm{EMIM}]\left[\mathrm{NTf}_{2}\right]$ & - & 1.86 & 1.68 & - & 1.86 & 1.68 & 39 \\
\hline$[\mathrm{EMMIM}]\left[\mathrm{NTf}_{2}\right]$ & - & 1.86 & 1.83 & - & 0.14 & 0.66 & 39 \\
\hline$[\mathrm{AMIM}]\left[\mathrm{NTf}_{2}\right]$ & 1.94 & 1.79 & 1.75 & 0.09 & 0.15 & 0.63 & 20 \\
\hline$[\mathrm{BMIM}]\left[\mathrm{NTf}_{2}\right]$ & 1.80 & - & - & 0.15 & - & - & 37 \\
\hline$[\mathrm{BMIM}]\left[\mathrm{NTf}_{2}\right]$ & 2.13 & - & - & 0.08 & - & - & 18 \\
\hline$[\mathrm{BMIM}]\left[\mathrm{NTf}_{2}\right]$ & 1.82 & 1.65 & - & 0.15 & 0.22 & - & 40 \\
\hline$[\mathrm{HMIM}]\left[\mathrm{NTf}_{2}\right]$ & 1.67 & - & - & 0.23 & - & - & 41 \\
\hline$[\mathrm{HMIM}]\left[\mathrm{NTf}_{2}\right]$ & 1.72 & 1.57 & - & 0.24 & 0.33 & - & 42 \\
\hline$[\mathrm{HMIM}]\left[\mathrm{NTf}_{2}\right]$ & 1.53 & 1.56 & - & 0.23 & 0.64 & - & 43 \\
\hline$[\mathrm{OMIM}]\left[\mathrm{NTf}_{2}\right]$ & 1.53 & 3.51 & - & 0.31 & 1.52 & - & 43 \\
\hline$\left[\mathrm{D}_{2} \mathrm{MIM}\right]\left[\mathrm{NTf}_{2}\right]$ & 1.31 & - & - & 0.72 & - & - & 44 \\
\hline$\left[\mathrm{C}_{6} \mathrm{H}_{13} \mathrm{OCH}_{2} \mathrm{MIM}\right]\left[\mathrm{NTf}_{2}\right]$ & 1.63 & - & - & 0.22 & - & - & 45 \\
\hline$\left[\left(\mathrm{C}_{6} \mathrm{H}_{13} \mathrm{OCH}_{2}\right)_{2} \mathrm{IM}\right]\left[\mathrm{NTf}_{2}\right]$ & 1.41 & - & - & 0.47 & - & - & 45 \\
\hline$\left[\mathrm{C}_{2} \mathrm{OHMIM}\right]\left[\mathrm{NTf}_{2}\right]$ & 1.99 & - & - & 0.05 & - & - & 36 \\
\hline$\left[\mathrm{COC}_{2} \mathrm{MIM}\right]\left[\mathrm{NTf}_{2}\right]$ & 1.89 & - & - & 0.10 & - & - & 36 \\
\hline$\left[(\mathrm{CO})_{2} \mathrm{IM}\right]\left[\mathrm{NTf}_{2}\right]$ & 2.13 & - & - & 0.05 & - & - & 36 \\
\hline$[\mathrm{CPMIM}]\left[\mathrm{NTf}_{2}\right]$ & 2.41 & - & - & 0.02 & - & - & 18 \\
\hline$[\mathrm{CPMMIM}]\left[\mathrm{NTf}_{2}\right]$ & 2.16 & - & - & 0.04 & - & - & 19 \\
\hline$\left[\mathrm{COC}_{2} \mathrm{MMOR}\right]\left[\mathrm{NTf}_{2}\right]$ & 2.13 & 1.97 & 1.82 & 0.07 & 0.12 & 0.57 & 46 \\
\hline$\left[\mathrm{N}-\mathrm{C}_{3} \mathrm{OHMMOR}\right]\left[\mathrm{NTf}_{2}\right]$ & 2.37 & 2.58 & 2.07 & 0.02 & 0.05 & 0.28 & 47 \\
\hline$[\mathrm{PMPIP}]\left[\mathrm{NTf}_{2}\right]$ & 1.99 & - & - & 0.11 & - & - & 48 \\
\hline$[\mathrm{BMPIP}]\left[\mathrm{NTf}_{2}\right]$ & 1.75 & - & - & 0.17 & - & - & 49 \\
\hline$[$ PeMPIP $]\left[\mathrm{NTf}_{2}\right]^{a}$ & 1.73 & 1.60 & - & 0.19 & 0.28 & - & 50 \\
\hline$[\mathrm{HMPIP}]\left[\mathrm{NTf}_{2}\right]$ & 1.63 & 1.56 & - & 0.23 & 0.34 & - & 50 \\
\hline$\left[\mathrm{COC}_{2} \mathrm{MPIP}\right]\left[\mathrm{NTf}_{2}\right]$ & 1.90 & 1.77 & 1.75 & 0.12 & 0.19 & 1.75 & 51 \\
\hline$\left[\mathrm{BCN}^{4} \mathrm{PY}\right]\left[\mathrm{NTf}_{2}\right]$ & 2.13 & 2.07 & 1.85 & 0.07 & 0.14 & 0.69 & 52 \\
\hline$[1,4 \mathrm{BMPY}]\left[\mathrm{NTf}_{2}\right]$ & 1.93 & - & - & 0.15 & - & - & 53 \\
\hline$[\mathrm{EPY}]\left[\mathrm{NTf}_{2}\right]$ & 2.20 & 1.95 & - & 0.08 & 0.13 & - & 54 \\
\hline$[\mathrm{EPY}]\left[\mathrm{NTf}_{2}\right]$ & 1.08 & - & - & 0.14 & - & - & 55 \\
\hline$[\mathrm{BPY}]\left[\mathrm{NTf}_{2}\right]$ & 1.37 & - & - & 0.16 & - & - & 55 \\
\hline$[\mathrm{PePY}]\left[\mathrm{NTf}_{2}\right]^{a}$ & 1.46 & - & - & 0.23 & - & - & 55 \\
\hline$\left[\mathrm{N}-\mathrm{C}_{3} \mathrm{OHPy}\right]\left[\mathrm{NTf}_{2}\right]$ & 2.15 & 2.04 & - & 0.05 & 0.10 & - & 56 \\
\hline [PMPYR][ $\left.\mathrm{NTf}_{2}\right]$ & 2.00 & - & - & 0.13 & - & - & 21 \\
\hline$[\mathrm{BMPYR}]\left[\mathrm{NTf}_{2}\right]$ & 1.72 & - & - & 0.15 & - & - & 43 \\
\hline$[\mathrm{BMPYR}]\left[\mathrm{NTf}_{2}\right]$ & 1.86 & - & - & 0.14 & - & - & 21 \\
\hline$[$ PeMPYR $]\left[\mathrm{NTf}_{2}\right]^{a}$ & 1.86 & - & - & 0.17 & - & - & 21 \\
\hline [HMPYR] $\left[\mathrm{NTf}_{2}\right]$ & 1.53 & - & - & 0.22 & - & - & 57 \\
\hline [HMPYR $]\left[\mathrm{NTf}_{2}\right]$ & 1.65 & - & - & 0.22 & - & - & 58 \\
\hline [OMPYR][ $\left.\mathrm{NTf}_{2}\right]$ & 1.52 & - & - & 0.31 & - & - & 57 \\
\hline [OMPYR $]\left[\mathrm{NTf}_{2}\right]$ & 1.58 & - & - & 0.33 & - & - & 58 \\
\hline$[\mathrm{DMPYR}]\left[\mathrm{NTf}_{2}\right]$ & 1.46 & - & - & 0.38 & - & - & 58 \\
\hline$\left[\mathrm{COC}_{2} \mathrm{MPYR}\right]\left[\mathrm{NTf}_{2}\right]$ & 1.91 & 1.78 & 1.7 & 0.11 & 0.17 & 1.70 & 59 \\
\hline 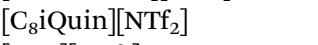 & 1.28 & - & - & 0.32 & - & - & 60 \\
\hline$\left[\mathrm{Et}_{3} \mathrm{~S}\right]\left[\mathrm{NTf}_{2}\right]$ & 2.09 & - & - & 0.09 & - & - & 61 \\
\hline$\left[\mathrm{N}_{1,1,1,2} \mathrm{OH}\right]\left[\mathrm{NTf}_{2}\right]$ & 2.22 & 2.03 & 0.97 & 0.04 & 0.06 & 0.24 & 62 \\
\hline$\left[\mathrm{N}_{1,1,1,4}\right]\left[\mathrm{NTf}_{2}\right]$ & 1.84 & 0.57 & - & 0.11 & 0.16 & - & 63 \\
\hline$\left[\mathrm{N}_{1,1,1,6}\right]\left[\mathrm{NTf}_{2}\right]$ & 0.88 & - & - & 0.84 & - & - & 17 \\
\hline$\left[\mathrm{N}_{1,1,1,8}\right]\left[\mathrm{NTf}_{2}\right]$ & 1.54 & - & - & 0.26 & - & - & 64 \\
\hline
\end{tabular}


Table 8 (Contd.)

\begin{tabular}{|c|c|c|c|c|c|c|c|}
\hline \multirow[b]{2}{*}{ Ionic liquid abbreviation } & \multicolumn{3}{|l|}{$S_{12}^{\infty}$} & \multicolumn{3}{|l|}{$k_{12}^{\infty}$} & \multirow[b]{2}{*}{ Ref. } \\
\hline & Hexane/hexene & Cyclohexane/cyclohexene & Ethylbenzene/styrene & Hexene & Cyclohexene & Styrene & \\
\hline$\left[\mathrm{N}_{1,4,4,4}\right]\left[\mathrm{NTf}_{2}\right]$ & 1.55 & - & - & 0.23 & - & - & 64 \\
\hline$\left[\mathrm{N}_{1,8,8,8}\right]\left[\mathrm{NTf}_{2}\right]$ & 1.27 & - & - & 1.16 & - & - & 65 \\
\hline$\left[\mathrm{N}_{2,2,2,8}\right]\left[\mathrm{NTf}_{2}\right]$ & 1.54 & 1.48 & 1.65 & 0.28 & 0.40 & 1.39 & 66 \\
\hline$\left[\mathrm{P}_{6,6,6,1,4}\right]\left[\mathrm{NTf}_{2}\right]$ & 1.21 & - & - & 1.09 & - & - & 68 \\
\hline$\left[\mathrm{P}_{6,6,6,1,4}\right]\left[\mathrm{NTf}_{2}\right]$ & 1.19 & - & - & 0.98 & - & - & 69 \\
\hline
\end{tabular}

selectivities for [BzMIM][DCA] are much larger than those for $[\mathrm{BzMIM}]\left[\mathrm{NTf}_{2}\right]$ for all separation cases. However, the capacity is two to three times larger for [BzMIM] $\left[\mathrm{NTf}_{2}\right]$ in comparison with [BzMIM][DCA]. The largest values of selectivity for the hexane (1)/hex-1-ene (2) separation are for $[\mathrm{DCA}]^{-}$-based ILs at $T=$ 328.15 K which are: 1-(3-hydroxypropyl)methylimidazolium dicyanamide, $\left[N-\mathrm{C}_{3} \mathrm{OHMIM}\right][\mathrm{DCA}]\left(S_{12}^{\infty}=2.79\right)^{36}>[\mathrm{AMIM}][\mathrm{DCA}]$ $\left(S_{12}^{\infty}=2.51\right)^{16}>[\mathrm{BzMIM}][\mathrm{DCA}]\left(S_{12}^{\infty}=2.50\right)$. The largest values of selectivity for the cyclohexane (1)/cyclohexene (2) separation are for [DCA $]^{-}$-based ILs at $T=328.15 \mathrm{~K}$ which are: [AMIM][DCA] $\left(S_{12}^{\infty}=2.51\right)^{16}>[\mathrm{BzMIM}][\mathrm{DCA}]\left(S_{12}^{\infty}=2.46\right)$. The largest values of selectivity for the ethylbenzene (1)/styrene (2) separation are for [DCA $]^{-}$-based ILs at $T=328.15 \mathrm{~K}$ which are: 1-butyl-4methylpyridinium dicyanamide, [BMPY][DCA] $\left(S_{12}^{\infty}=2.31\right)^{35}>$ $[\mathrm{AMIM}][\mathrm{DCA}]\left(S_{12}^{\infty}=2.24\right)^{16}>[\mathrm{BzMIM}][\mathrm{DCA}]\left(S_{12}^{\infty}=2.16\right)$. The largest values of selectivity for the hexane (1)/hex-1-ene (2) separation for $\left[\mathrm{NTf}_{2}\right]^{-}$-based ILs at $T=328.15 \mathrm{~K}$ are: 1-ethyl-3methyl imidazoliumbis $\{$ (trifluoromethyl)sulfonyl $\}$ imide, [EMIM] $\left[\mathrm{NTf}_{2}\right]\left(S_{12}^{\infty}=3.02\right)^{38}>[\mathrm{CPMIM}]\left[\mathrm{NTf}_{2}\right]\left(S_{12}^{\infty}=2.41\right)^{18}>1-(3-$ hydroxypropyl)methylmorpholinium bis\{(trifluoromethyl) sulfonyl $\}$ imide, $\left[N-\mathrm{C}_{3} \mathrm{OHMOR}\right]\left[\mathrm{NTf}_{2}\right]\left(S_{12}^{\infty}=2.37\right)^{47}>\left[\mathrm{N}_{1,1,1,2} \mathrm{OH}\right]$ $\left[\mathrm{NTf}_{2}\right]\left(S_{12}^{\infty}=2.22\right)^{62}>[\mathrm{EPY}]\left[\mathrm{NTf}_{2}\right]\left(S_{12}^{\infty}=2.20\right) .{ }^{54}$ The largest values of selectivity for the cyclohexane (1)/cyclohexene (2) separation for $\left[\mathrm{NTf}_{2}\right]^{-}$-based ILs at $T=328.15 \mathrm{~K}$ are: 1-octyl-3methyl imidazolium bis $\{$ (trifluoromethyl)sulfonyl $\}$ imide, $[\mathrm{OMIM}]\left[\mathrm{NTf}_{2}\right]\left(S_{12}^{\infty}=3.51\right)^{43}>\left[N-\mathrm{C}_{3} \mathrm{OHMOR}\right]\left[\mathrm{NTf}_{2}\right]\left(S_{12}^{\infty}=2.58\right) .{ }^{47}$ The largest values of selectivity for the ethylbenzene (1)/styrene (2) separation for $\left[\mathrm{NTf}_{2}\right]^{-}$-based ILs at $T=328.15 \mathrm{~K}$ are: $[\mathrm{N}-$ $\left.\mathrm{C}_{3} \mathrm{OHMOR}\right]\left[\mathrm{NTf}_{2}\right]\left(S_{12}^{\infty}=2.07\right)^{47}>\left[\mathrm{BCN}^{4} \mathrm{PY}\right]\left[\mathrm{NTf}_{2}\right]\left(S_{12}^{\infty}=1.85\right)^{52}>$ [EMMIM] $\left[\mathrm{NTf}_{2}\right]\left(S_{12}^{\infty}=1.83\right) \cdot{ }^{39}$

Summing up, for all three separation cases, the $[\mathrm{DCA}]^{-}$based ILs reveal larger selectivities than those for $\left[\mathrm{NTf}_{2}\right]^{-}$-based ILs (with the exception of [EMIM] $\left[\mathrm{NTf}_{2}\right],{ }^{38}$ which is probably an experimental error in comparison with other results of the same IL). This fact reveals that the interaction of unsaturated hydrocarbons and aromatic hydrocarbons with $[\mathrm{DCA}]^{-}$-based ILs is larger than that with aliphatic hydrocarbons. Unfortunately, the high selectivity of the above-mentioned ILs are accompanied with low capacity. Among the 67 ILs listed in Table 8 , the capacity is in a range $\left(k_{2}^{\infty}\right.$ is from 0.02 to 2.04$)$ for hex-1-ene, $\left(k_{2}^{\infty}\right.$ is from 0.05 to 1.86$)$ for cyclohexene, and $\left(k_{2}^{\infty}\right.$ is from 0.24 to 1.75 ) for styrene at $T=328.15 \mathrm{~K}$. The highest capacity for the investigated ILs is exhibited by [BzMIM] $\left.\mathrm{NTf}_{2}\right]$ for hexene $\left(k_{2}^{\infty}=0.11\right)$ and for styrene $\left(k_{2}^{\infty}=0.76\right)$. The introduction of a benzyl group in the imidazolium cation has slightly increased the capacity, especially for styrene, with the selectivity on the same level in comparison to $[\mathrm{AMIM}][\mathrm{DCA}]^{16}$ and with slightly lower selectivity in comparison with [AMIM] $\left[\mathrm{NTf}_{2}\right]^{20}$ The replacement of the ethyl group by the allyl group at the cation for $\left[\mathrm{NTf}_{2}\right]^{-}$-based ILs has caused the opposite effect on the selectivity in the ethylbenzene (1)/styrene (2) separation, but increases the capacity for cyclohexene $\left(k_{2}^{\infty}=1.86\right)^{39}$ and for styrene $\left(k_{2}^{\infty}=1.68\right) .^{39}$

\section{Conclusions}

In this work, we have studied the potential use of 1-benzyl-3methylimidazolium dicyanamide, [BzMIM][DCA] and 1-benzyl3-methylimidazolium bis\{(trifluoromethyl)sulfonyl $\}$ imide, $[\mathrm{BzMIM}]\left[\mathrm{NTf}_{2}\right]$ ILs in three processes for separation, viz. hexane/ hex-1-ene, cyclohexane/cyclohexene, and ethylbenzene/styrene. For that purpose, experimental measurements were performed for the activity coefficients at infinite dilution for 64 solutes in both ILs at six temperatures ranging between (318.15 and 368.15 ) K. In addition, thermal properties, densities, and viscosities of both ILs were also measured as a function of temperature. The interactions of various types of organic solutes and water with two ionic liquids at infinite dilution were discussed and shown with regard to the activity coefficients, the gas-liquid-partition coefficients and the thermodynamic functions. Using the reported experimental data, along with other data from literature, the impact of the ILs cation and anion in the three chosen separation problems was analyzed. The reported results show high values of selectivity and low values of capacity for [BzMIM][DCA] and the opposite trend for [BzMIM] $\left[\mathrm{NTf}_{2}\right]$ ionic liquid as a separation agent. However, [BzMIM] [DCA] has exhibited adequate extraction properties for all separation processes with high values of selectivities which are similar to $[\mathrm{AMIM}][\mathrm{DCA}]^{16}$ measured by us earlier. Moreover, densities and viscosities of [BzMIM] [DCA] were lower than those of $[\mathrm{BzMIM}]\left[\mathrm{NTf}_{2}\right]$ and slightly higher than those for [AMIM] [DCA]. ${ }^{16,27}$ Therefore, in this context, the conclusion must be 
made that the presence of the benzyl group in the imidazolium cation has not considerably increased the selectivity in both ILS in comparison with the allyl group, but has increased the capacity, especially for styrene.

\section{Acknowledgements}

The authors M. K., M. W. and U. D. are grateful to our colleagues from the Thermodynamic Research Unit, School of Chemical Engineering, University of KwaZulu-Natal, for co-operation. This work has been supported by the Ministry of Science and Higher Education in Poland in the years 2015-2017 (Project "Iuventus Plus" No. IP2014051373).

\section{References}

1 N. V. Plechkova and K. S. Seddon, Chem. Soc. Rev., 2008, 37, 123-150.

2 J. P. Hallet and T. Welton, Chem. Rev., 2011, 111, 3508-3576. 3 U. Domańska, Ionic Liquids in Chemical Analysis, General Review of Ionic Liquids and Their Properties, CRC Pres, Taylor \& Francis Group, Abingdon, UK, 2008, ch. 1.

4 A. Cole, Ionic Liquids in Separation Technology, Elsevier Science and Technology, Research and Markets, 2014, http://www.researchandmarkets.com/reports/2899469/ionicliquids-in-separation-technology.htm.

5 G. W. Meindersma, A. R. Hansmeier and A. B. de Haan, Ind. Eng. Chem. Res., 2010, 49, 7530-7540.

6 A. R. Hansmeier, G. W. Meindersma and A. B. de Haan, Green Chem., 2011, 13, 1907-1913.

7 K. Kędra-Królik, F. Mutelet and J.-N. Joubert, Ind. Eng. Chem. Res., 2011, 50, 2296-2306.

8 U. Domańska and M. Wlazło, Fuel, 2014, 134, 114-125.

9 A. Nann, C. Held and G. Sadowski, Ind. Eng. Chem. Res., 2013, 52, 18472-18481.

10 M. Bülow, C. J. Guo, D. Shen, F. R. Fitch, A. I. Shirley and V. A. Malik, Separation of alkenes and alkanes, US Pat., 6200366, 2001, http:/www.google.com/patents/US6200366? utm_source=gb-gplus-sharePatent.

11 J. Bergh, C. Gücüyener, E. A. Pidko, E. J. M. Hensen, J. Gascon and F. Kapteijn, Chem.-Eur. J., 2011, 17, 88328840 .

12 D. Peralta, G. Chaplais, A. Simon-Masseron, K. Barthelet, C. Chizallet, A. A. Quoineaud and G. D. Pirngruber, J. Am. Chem. Soc., 2012, 134, 8115-8126.

13 V. Mokrushin, D. Assenbaum, N. Paape, D. Gerhard, L. Mokrushina, P. Wasserscheid, W. Arlt, H. Kistenmacher, S. Neuendorf and V. Göke, Chem. Eng. Technol., 2010, 33, 63-73.

14 Z. Lei, W. Arlt and P. Wasserscheid, Fluid Phase Equilib., 2006, 241, 290-299.

15 U. Domańska, M. Wlazło and M. Karpińska, Fluid Phase Equilib., 2016, 417, 50-61.

16 M. Wlazło, J. Gawkowska and U. Domańska, Ind. Eng. Chem. Res., 2016, 55, 5054-5056.
17 F. Mutelet, A. L. Revelli, J.-N. Jaubert, L. M. Sprunger, W. E. Acree Jr and G. A. Baker, J. Chem. Eng. Data, 2010, 55, 234-242.

18 J. Zhang, Q. Zhang, B. Qiao and Y. Deng, J. Chem. Eng. Data, 2007, 52, 2277-2283.

19 U. Domańska, E. V. Lukoshko and M. Królikowski, J. Chem. Thermodyn., 2013, 61, 126-131.

20 M. Wlazło, M. Karpińska and U. Domańska, J. Chem. Thermodyn., 2016, 102, 39-47.

21 F. Mutelet, E.-S. R. E. Hassan, T. W. Stephens, W. E. Acree Jr and G. A. Baker, J. Chem. Eng. Data, 2013, 58, 2210-2218.

22 P. S. Kulkarni, L. C. Branco, J. G. Crespo, M. C. Nunes, A. Raymundo and C. A. M. Afonso, Chem.-Eur. J., 2007, 13, 8478-8488.

23 S. V. Dzyuba and R. A. Bartsch, ChemPhysChem, 2002, 3, 161-166.

24 T. Mandai, A. Matsumura, M. Imanari and K. Nishikawa, J. Phys. Chem. B, 2012, 116, 2090-2095.

25 H. Shirota, H. Matsuzaki, S. Ramati and J. F. Wishart, J. Phys. Chem. B, 2015, 119, 9173-9187.

26 S. M. Mahurin, T. Dai, J. S. Yeary, H. Luo and S. Dai, Ind. Eng. Chem. Res., 2011, 50, 14061-14069.

27 M. Larriba, P. Navarro, M. Gonzalez-Miquel, S. Omar, J. Palomar, J. García and F. Rodríguez, Chem. Eng. Res. Des., 2016, 109, 561-572.

28 B. Gabri, A. Sander, M. C. Bubalo and D. Macut, Sci. World J., 2013, 2013, 512953, DOI: 10.1155/2013/512953.

29 C. A. Ohlin, P. J. Dyson and G. Laurenczy, Chem. Commun., 2004, 1070-1071.

30 D. H. Everett, Trans. Faraday Soc., 1965, 61, 1637-1645.

31 A. J. B. Cruickshank, B. W. Gainey, C. P. Hicks, T. M. Letcher, R. W. Moody and C. L. Young, Trans. Faraday Soc., 1969, 65, 1014-1031.

32 Design institute for physical properties, sponsored by AICHE (2005; 2008; 2009; 2010). Dippr project 801-full version. Design institute for physical property research/aiche. Online version available at: http://knovel.com/web/portal/browse/ display?_ext_knovel_display_bookid $=1187$ \&verticalid $=0$.

33 B. E. Poling and J. M. Prausnitz, Properties of Gases and Liquids, McGraw-Hill Publishing, 2001, http:// lib.myilibrary.com? $\mathrm{ID}=91317$.

34 U. Domańska, M. Królikowska, W. E. Acree Jr and G. A. Baker, J. Chem. Thermodyn., 2011, 43, 1050-1057.

35 M. Królikowski and M. Królikowska, J. Chem. Thermodyn., 2014, 68, 138-144.

36 A.-L. Revelli, F. Mutelet, J.-N. Jaubert, M. Garcia-Martinez, L. M. Sprunger, W. E. Acree Jr and G. A. Baker, J. Chem. Eng. Data, 2010, 55, 2434-2443.

37 M. Krummen, P. Wasserscheid and J. Gmehling, J. Chem. Eng. Data, 2002, 47, 1411-1417.

38 N. Deenadajalu, T. M. Letcher and P. Reddy, J. Chem. Eng. Data, 2005, 50, 105-108.

39 A. Heintz, D. V. Kulikov and S. P. Verevkin, J. Chem. Eng. Data, 2002, 47, 894-899.

40 A. Heintz, L. M. Casás, I. A. Nesterov, V. N. Emel'yanenko and S. P. Verevkin, J. Chem. Eng. Data, 2005, 50, 1510-1514. 
41 T. M. Letcher, A. Marciniak, M. Marciniak and U. Domańska, J. Chem. Thermodyn., 2005, 37, 1327-1331.

42 A. Heintz and S. P. Verevkin, J. Chem. Eng. Data, 2006, 51, 434-437.

43 R. Kato and J. Gmehling, J. Chem. Thermodyn., 2005, 37, 603619.

44 J.-C. Moise, F. Mutelet, J. N. Jaubert, L. M. Grubbs, W. E. Acree Jr and G. A. Baker, J. Chem. Eng. Data, 2011, 56, 3106-3114.

45 U. Domańska and A. Marciniak, Fluid Phase Equilib., 2009, 286, 154-161.

46 A. Marciniak and M. Wlazło, J. Chem. Thermodyn., 2012, 47, 382-388.

47 M. Wlazło, A. Marciniak, M. Zawadzki and B. Dudkiewicz, J. Chem. Thermodyn., 2015, 86, 154-161.

48 U. Domańska and K. Paduszyński, J. Chem. Thermodyn., 2010, 42, 1361-1366.

49 K. Paduszyński and U. Domańska, J. Phys. Chem. B, 2011, 115, 8207-8215.

50 K. Paduszyński and U. Domańska, J. Chem. Thermodyn., 2013, 60, 169-173.

51 A. Marciniak and M. Wlazło, J. Chem. Thermodyn., 2012, 49, 137-145.

52 M. Wlazło, M. Karpińska and U. Domańska, J. Chem. Thermodyn., 2016, 97, 253-260.

53 U. Domańska and A. Marciniak, J. Chem. Thermodyn., 2009, 41, 1350-1355.

54 R. Kato and J. Gmehling, Fluid Phase Equilib., 2004, 226, 3744.

55 P.-F. Yan, Q.-S. Liu, M. Yang, X.-M. Liu, Z.-C. Tan and U. Welz-Biermann, J. Chem. Thermodyn., 2010, 42, 14151422.
56 A. Marciniak, J. Chem. Thermodyn., 2011, 43, 1446-1452.

57 S. Nebig, V. Liebert and J. Gmehling, Fluid Phase Equilib., 2009, 277, 61-67.

58 W. E. Acree Jr, G. A. Baker, A.-L. Revelli, J.-Ch. Moise and F. Mutelet, J. Chem. Eng. Data, 2012, 57, 3510-3518.

59 A. Marciniak and M. Wlazło, J. Chem. Thermodyn., 2012, 54, 90-96.

60 U. Domańska, M. Zawadzki, M. Królikowska, M. M. Tshibangu, D. Ramjugernath and T. M. Letcher, J. Chem. Thermodyn., 2011, 43, 499-504.

61 U. Domańska and A. Marciniak, J. Chem. Thermodyn., 2009, 41, 754-758.

62 U. Domańska, P. Papis and J. Szydłowski, J. Chem. Thermodyn., 2014, 77, 63-70.

63 A. Heintz, T. V. Vasitsova, J. Safarov, E. Bich and S. P. Verevkin, J. Chem. Eng. Data, 2006, 51, 648-655.

64 W. E. Acree Jr, G. A. Baker, F. Mutelet and J.-C. Moise, J. Chem. Eng. Data, 2011, 56, 3688-3697.

65 N. V. Gwala, N. Deenadayalu, K. Tumba and D. Ramjugernath, J. Chem. Thermodyn., 2010, 42, 256-261.

66 M. Wlazło and U. Domańska, Sep. Purif. Technol., 2016, 162, 162-170.

67 T. Banerjee and A. Khanna, J. Chem. Eng. Data, 2006, 51, 2170-2177.

68 K. Tumba, T. M. Letcher, P. Naidoo and D. Ramjugernath, J. Chem. Thermodyn., 2013, 65, 159-167.

69 T. M. Letcher, D. Ramjugernath, M. Laskowska, M. Królikowski, P. Naidoo and U. Domańska, J. Chem. Eng. Data, 2008, 53, 2044-2049. 